\title{
Different Roles of BDNF in Nucleus Accumbens Core versus Shell during the Incubation of Cue-Induced Cocaine Craving and Its Long-Term Maintenance
}

\author{
Xuan Li, ${ }^{1}$ M.R. DeJoseph, ${ }^{2}$ Janice H. Urban, ${ }^{2}$ Amine Bahi, ${ }^{4}$ Jean-Luc Dreyer, ${ }^{5}$ Gloria E. Meredith, ${ }^{3}$ Kerstin A. Ford, ${ }^{1}$ \\ Carrie R. Ferrario, ${ }^{1}$ Jessica A. Loweth, ${ }^{1}$ and Marina E. Wolf ${ }^{1}$ \\ Departments of ${ }^{1}$ Neuroscience, ${ }^{2}$ Physiology and Biophysics, and ${ }^{3}$ Pharmaceutical Sciences, Rosalind Franklin University of Medicine and Science, North \\ Chicago, Illinois 60064, ${ }^{4}$ Department of Anatomy, United Arab Emirates University, Alabama-Ain, United Arab Emirates, and ${ }^{5}$ Division of Biochemistry, \\ Department of Medicine, University of Fribourg, CH-1700 Fribourg, Switzerland
}

Brain-derived neurotrophic factor (BDNF) contributes to diverse types of plasticity, including cocaine addiction. We investigated the role of BDNF in the rat nucleus accumbens (NAc) in the incubation of cocaine craving over 3 months of withdrawal from extended access cocaine self-administration. First, we confirmed by immunoblotting that BDNF levels are elevated after this cocaine regimen on withdrawal day 45 (WD45) and showed that BDNF mRNA levels are not altered. Next, we explored the time course of elevated BDNF expression using immunohistochemistry. Elevation of BDNF in the NAc core was detected on WD45 and further increased on WD90, whereas elevation in shell was not detected until WD90. Surface expression of activated tropomyosin receptor kinase B (TrkB) was also enhanced on WD90. Next, we used viral vectors to attenuate BDNF-TrkB signaling. Virus injection into the NAc core enhanced cue-induced cocaine seeking on WD1 compared with controls, whereas no effect was observed on WD30 or WD90. Attenuating BDNF-TrkB signaling in shell did not affect cocaine seeking on WD1 or WD45 but significantly decreased cocaine seeking on WD90. These results suggest that basal levels of BDNF transmission in the NAc core exert a suppressive effect on cocaine seeking in early withdrawal (WD1), whereas the late elevation of BDNF protein in NAc shell contributes to incubation in late withdrawal (WD90). Finally, BDNF protein levels in the NAc were significantly increased after ampakine treatment, supporting the novel hypothesis that the gradual increase of BDNF levels in NAc accompanying incubation could be caused by increased AMPAR transmission during withdrawal.

\section{Introduction}

Relapse after abstinence from cocaine is often induced by exposure to cocaine-associated cues. In rats, cue-induced cocaine seeking progressively increases over the first months of withdrawal from extended-access cocaine self-administration and remains elevated even 6 months after the last exposure (Neisewander et al., 2000; Grimm et al., 2001; Lu et al., 2004b; c; Sorge and Stewart, 2005; Pickens et al., 2011). This phenomenon, termed incubation, is reminiscent of findings in cocaine addicts (Gawin and Kleber, 1986). In parallel with incubation of cocaine

\footnotetext{
Received June 21, 2012; revised 0ct. 9, 2012; accepted Nov. 19, 2012

Author contributions:X.L., J.H.U., and M.E.W. designed research;X.L., M.R.D., K.A.F., C.R.F., and J.A.L. performed research; A.B., J.-L.D., and G.E.M. contributed unpublished reagents/analytic tools;X.L., M.R.D., and J.H.U. analyzed data; X.L. and M.E.W. wrote the paper.

This work was supported by NIDA Grants DA015835 and DA029099 to M.E.W. Some of the results were presented previously in poster form (Li et al., 2009, 2010, 2011). We thank Drs. Joost Verhaagen, Eric M. Ehlert, and Amy W. Lasek for kindly providing us with viral vectors and technical advice, Cortex Pharmaceuticals for their gift of ampakine CX929, Drs. Mark Varney and Gary Lynch for advice on CX929 experiments, and Corinne Schneider for assistance with RT-PCR.

The authors declare no competing financial interests.

Correspondence should be addressed to Dr. Marina E. Wolf, Department of Neuroscience, Rosalind Franklin University of Medicine and Science, 3333 Green Bay Road, North Chicago, IL 60064. E-mail: marina.wolf@rosalindfranklin.edu.

C. R. Ferrario's present address: Department of Pharmacology, University of Michigan, Ann Arbor, MI 48109. DOI:10.1523/JNEUROSCI.3082-12.2013

Copyright $\odot 2013$ the authors $\quad 0270-6474 / 13 / 331130-13 \$ 15.00 / 0$
}

craving, brain-derived neurotrophic factor (BDNF) protein levels show a time-dependent increase in the nucleus accumbens (NAc), ventral tegmental area (VTA), and amygdala (Grimm et al., 2003). This suggests that BDNF may contribute to incubation.

Other results also implicate BDNF in cocaine seeking but indicate regional differences in its function. For example, elevation of BDNF in the medial prefrontal cortex (mPFC) suppresses cocaine seeking (Berglind et al., 2007, 2009;Sadri-Vakili et al., 2010; Whitfield et al., 2011), whereas elevation of BDNF in the VTA (Lu et al., 2004a) and NAc shell (Graham et al., 2007; Graham et al., 2009) facilitates cocaine seeking. Similar studies have not been performed in the NAc core, and BDNF's role in seeking after long withdrawals $(>15 \mathrm{~d}$ ) has not been examined in either NAc subregion. Core-shell differences are possible given different effects of cocaine exposure on BDNF and TrkB expression in these regions (Filip et al., 2006; Graham et al., 2007; Graham et al., 2009).

Another important adaptation accompanying incubation is the accumulation of GluA2-lacking $\mathrm{Ca}^{2+}$-permeable AMPA receptors (CP-AMPARs) in NAc synapses (Conrad et al., 2008). In contrast to the $\mathrm{Ca}^{2+}$-impermeable GluA1A2-containing AMPARs that dominate in the NAc of drug-naive rats (Reimers et al., 2011), CP-AMPARs exhibit higher conductance and can be identified based on inward rectification resulting from voltagedependent polyamine block (Isaac et al., 2007; Liu and Zukin, 2007). CP-AMPARs are first detected in the NAc core on approx- 
imately withdrawal day 30 (WD 30) (Wolf and Tseng, 2012), and their blockade on WD45 prevents the expression of incubated cueinduced cocaine seeking (Conrad et al., 2008). They also accumulate in shell (Mameli et al., 2009; McCutcheon et al., 2011). Previous in vitro studies showed that BDNF promotes synaptic delivery of $\mathrm{CP}$ AMPARs (Caldeira et al., 2007, Li and Keifer, 2008, 2009; Keifer and Zheng, 2010), and our in vivo study demonstrated that BDNF infusion into the NAc core transiently increased GluA1 surface expression without affecting GluA2 or GluA3, suggesting an increase in CP-AMPARs (Li and Wolf, 2011a).

In light of these previous findings, we tested the hypothesis that elevated BDNF transmission in the NAc underlies incubation of cocaine craving and accompanying CP-AMPAR accumulation. Contrary to our hypothesis, we found that BDNF in NAc shell contributes to incubation only in late withdrawal, whereas core BDNF initially suppresses incubation. Additionally, time course data raised the possibility that enhanced AMPAR transmission during incubation triggers the elevation of BDNF, rather than vice versa. A final experiment explored this possibility using ampakines (Lynch and Gall, 2006) to elevate AMPAR transmission.

\section{Materials and Methods}

Subjects. Male Sprague-Dawley rats (250-275 g) were purchased from Harlan and housed with food and water available ad libitum. Rats were allowed to acclimate $4-7 \mathrm{~d}$ before any experimental procedures. For self-administration experiments, rats were housed individually in a reversed light cycle room ( $12 \mathrm{~h} / 12 \mathrm{~h}$ light/dark), with lights on at 19:00 h. All self-administration sessions and cue-induced cocaine-seeking tests were performed in the dark phase of the cycle with food and water available throughout the sessions. For other experiments, rats were housed in pairs in a normal light cycle room $(12 \mathrm{~h} / 12 \mathrm{~h}$ light/dark), with lights on at 07:00 h. All procedures were approved by the Institutional Animal Care and Use Committee of Rosalind Franklin University of Medicine and Science.

Catheter implantation and self-administration training. Rats were anesthetized by isoflurane gas (Henry Schein). Then a Silastic catheter (Plastics One) was inserted into the right internal jugular vein and passed subcutaneously to the mid-scapular region. Rats also received the analgesic banamine ( $2 \mathrm{mg} / \mathrm{kg}$, s.c.) before surgical procedures, and catheters were flushed daily with sterile $0.9 \%$ saline solution. Self-administration training sessions started 5-7 d after surgeries and continued for 10 consecutive days $(6 \mathrm{~h} / \mathrm{d})$ as previously described (Conrad et al., 2008). Briefly, rats were placed in self-administration chambers (MED Associates) equipped with two nose-poke holes. Responding in one hole (active) resulted in an intravenous infusion of cocaine $(0.5 \mathrm{mg} / \mathrm{kg}$ in 32 $\mu \mathrm{l} /$ infusion) or saline ( $32 \mu \mathrm{l} /$ infusion) paired with the illumination of a cue light. Responding in the other hole (inactive) had no consequences. Rats were brought back to their home cages after each $6 \mathrm{~h}$ training session. A fixed ratio 1 schedule was used to deliver the cocaine with a $20 \mathrm{~s}$ timeout period. Responses in both holes (active and inactive) and total infusions were recorded for each training session.

Cue-induced cocaine-seeking tests. After the 10 day cocaine selfadministration training described above (Catheter implantation and self-administration training), rats were housed in their home cages and handled several times per week during the withdrawal period. On the test day, rats were brought back to the self-administration training boxes, and cue-induced cocaine seeking was tested under extinction conditions, in which responding in the active hole led to no cocaine infusion but only the presentation of the light cue previously paired with drug delivery during the training sessions. Responses in the active hole were recorded and used as a measure of cocaine seeking. All seeking tests lasted $30 \mathrm{~min}$, except the test shown in Figure 6 C (60 min).

Viral vectors and intracranial infusion. For behavioral studies, rats in all 6 cohorts (see Figs. 6 to Fig. 9) received bilateral intracranial viral vector infusions into either NAc core or shell immediately after the catheter implantation. The coordinates for NAc core were as follows: anteroposterior $(\mathrm{AP})+1.2 \mathrm{~mm}$; lateral $(\mathrm{L})+2.6 \mathrm{~mm}\left(6^{\circ}\right.$ angle $)$; and dorsoventral
(DV) $-7.0 \mathrm{~mm}$ (Paxinos and Watson, 1998). The coordinates for NAc shell were as follows: AP $+1.2 \mathrm{~mm}$; $\mathrm{L}+1.5 \mathrm{~mm}\left(6^{\circ}\right.$ angle $)$; and DV -7.0 $\mathrm{mm}$. Anesthetized by isoflurane gas, rats were mounted onto a stereotaxic frame and viral vectors were infused directly through Hamilton syringes. Our prior results showed that the virus injection volumes used in our studies produce an area of infection confined to the targeted region; that is, injections aimed at the core did not lead to appreciable virus spread into the shell (Li and Wolf, 2011b). The lentiviruses (LVs) used in this study (kind gifts from Drs. Amine Bahi and Jean-Luc Dreyer) were LV-GFP $\left(8 \times 10^{9} \mathrm{IU} / \mathrm{ml}\right)$, LV-TrkBsiRNA $\left(8 \times 10^{9} \mathrm{IU} / \mathrm{ml}\right)$, and LV-TrkBT1 $\left(8 \times 10^{9} \mathrm{IU} / \mathrm{ml}\right)$. They were infused into the NAc at a rate of $0.2 \mu \mathrm{l} / \mathrm{min}(4 \mu \mathrm{l} / \mathrm{side})$ with $5 \mathrm{~min}$ allowed for diffusion before withdrawing the syringe. In a previous study, the expression and functional efficacy of these viral vectors were demonstrated $\sim 20 \mathrm{~d}$ after their injection into the NAc (Bahi et al., 2008). Even as long as 12 weeks after intra-NAc injection of LV-TrkBsiRNA, there is still a robust decrease $(\sim 60 \%)$ in TrkB mRNA levels in the NAc [control, $100 \pm 22.12(n=7)$; LVTrkBsiRNA, $43.09 \pm 6.29(n=10) ; p<0.05, t$ test (Bahi and Dreyer, unpublished observations)]. These studies, as well as our present results, verify that LV expression persists over the timeframe of our experiments. The adeno-associated virus (AAV) vectors used in this study (kind gifts from Drs. Joost Verhaagen and Eric M. Ehlert) were AAV-GFP $\left(1 \times 10^{9}\right.$ $\mathrm{TU} / \mathrm{ml})$, AAV-TrkB.T1 with FLAG $\left(3.6 \times 10^{9} \mathrm{TU} / \mathrm{ml}\right)$, and AAVTrkB.T1 with GFP $\left(3 \times 10^{9} \mathrm{TU} / \mathrm{ml}\right)$. We pooled the latter two viruses to generate the AAV-TrkB.T1 group. AAV viral vectors were infused at a rate of $0.1 \mu \mathrm{l} / \mathrm{min}(0.5 \mu \mathrm{l} / \mathrm{side})$ with $10 \mathrm{~min}$ allowed for diffusion. Their expression and functional efficacy have been established in previous studies (Eisch et al., 2003; Wit et al., 2006). For example, cotransfection of AAV-TrkB and AAV-TrkB.T1 in vitro significantly reduced BDNFinduced phosphorylation of TrkB (Wit et al., 2006). Furthermore, FLAG immunostaining on WD90 confirmed virus expression throughout the timeframe of our experiments (see Figs. 7 and 9). For biochemical studies (see Fig. 10), we used LV-GFP and LV-BDNF-GFP made by Dr. Amy W. Lasek (Ernest Gallo Clinic and Research Center, Department of Neurology, University of California, San Francisco, Emeryville, California). Expression of these viruses throughout the timeframe of the experiments was confirmed by GFP or BDNF immunohistochemistry ( $21 \mathrm{~d}$ after virus injection; see Fig. 10A) or immunoblotting ( $47 \mathrm{~d}$ after virus injection; see Fig. 10B). The goal of the LV-BDNF-GFP experiment was to produce a long-term elevation of BDNF levels in the NAc core or shell (47 d), dissect NAc tissue, and use a protein crosslinking assay to determine whether AMPAR surface expression was elevated. To selectively and accurately dissect the region of NAc expressing LV-GFP, we used a GFP flashlight and filter glasses as described previously (Li and Wolf, 2011b). However, the GFP signal produced by LV-BDNF-GFP was not strong enough to visualize. To overcome this, we used a mixture of LV-BDNFGFP and LV-GFP $(8: 1, \mathrm{v} / \mathrm{v})$ to produce a stronger GFP signal, enabling us to use the GFP flashlight to identify and dissect the region of viral expression. Therefore, after rats were anesthetized with ketamine-xylazine mixture $(80$ and $10 \mathrm{mg} / \mathrm{kg}$, respectively), either LV-GFP virus alone or the mix of LV-BDNF-GFP $\left(1.2 \times 10^{7} \mathrm{pg} / \mathrm{ml}\right)$ and LV-GFP $\left(7.1 \times 10^{7} \mathrm{pg} / \mathrm{ml}\right)$ was infused directly into NAc core or shell with Hamilton syringes $(0.2$ $\mu \mathrm{l} / \mathrm{min}$; $3 \mu \mathrm{l} / \mathrm{side} ; 5 \mathrm{~min}$ diffusion time) using the same coordinates described above. Forty-seven days after the infusion, GFP-expressing regions from NAc core or shell were collected for the protein crosslinking assay (see Biotinylation and protein crosslinking).

Histology. At the end of each behavioral experiment, rats were deeply anesthetized and transcardially perfused first with $0.9 \%$ saline and then with $4 \%$ paraformaldehyde (PFA; 158127, Sigma) in PBS. Brains were postfixed in $4 \%$ PFA overnight, and then $40 \mu \mathrm{m}$ sections were obtained by cryostat. For experiments using LV-GFP, LV-TrkBsiRNA, and LVTrkB.T1, sections were mounted on gelatin-coated slides and locations of viral injection sites were determined after Cresyl Violet (C1791, Sigma) staining. Only rats with both injection tips in the target region (NAc core or shell) were included for statistical analysis. For experiments using AAV-GFP or AAV-TrkB.T1, sections were processed for either FLAG or GFP immunohistochemistry, as described previously (Lobbestael et al., 2010 ), to verify viral expression and injection placement. Briefly, sections were first blocked with $10 \%$ donkey serum in PBS-T (PBS with $0.1 \%$ 
Triton X-100) and then incubated with primary antibody (FLAG: 1:5000, F7425, Sigma; GFP: 1:5000, ab290, Abcam) overnight. After three PBS-T washes, sections were incubated with a Cy3-AffiniPure Donkey AntiRabbit IgG (1: 500 in PBS, 711-165-152, Jackson ImmunoResearch Laboratories) for $2 \mathrm{~h}$ at room temperature and then mounted with PVADABCO coverslipping solution. Slides were examined by epifluorescence microscopy (Eclipse C600; Nikon), and only rats with viral expression in the target region were included in the analysis.

BDNF immunohistochemistry. Forty-five days or $90 \mathrm{~d}$ after the last day of saline or cocaine self-administration training, rats were decapitated and brains were fixed in $2.5 \%$ PFA in PBS on ice for $2 \mathrm{~h}$. Then brains were transferred to $30 \%$ sucrose in $2.5 \%$ PFA and fixed for another $24 \mathrm{~h}$ at $4^{\circ} \mathrm{C}$. Sections $(40 \mu \mathrm{m})$ were obtained using a cryostat and stored in cryoprotectant $(23.8 \%$ glycerol and $28.6 \%$ ethylene glycol in $0.1 \mathrm{M} \mathrm{PBS})$ at $-20^{\circ} \mathrm{C}$. For immunohistochemistry, free-floating sections were first washed in PBS for 15 min and then blocked with $10 \%$ donkey serum with $0.1 \%$ Triton X-100 for $1 \mathrm{~h}$. Next, sections were incubated with primary antibody (1:1000 in 4\% donkey serum; AB1779, Millipore) overnight at $4^{\circ} \mathrm{C}$. After a 30 min wash in PBS, sections were incubated with a Cy3AffiniPure Donkey Anti-Rabbit IgG (1: 500 in PBS, 711-165-152, Jackson ImmunoResearch Laboratories) for $3 \mathrm{~h}$ at room temperature and then mounted with PVA-DABCO coverslipping solution. In preliminary control studies (data not shown), we validated the specificity of the BDNF immunostaining by omitting primary antibody. We also verified that BDNF immunoreactivity was high in cortex but low in the NAc of drug-naive rats, which was consistent with previous studies (Conner et al., 1997). Visualization of BDNF immunoreactivity was accomplished by epifluorescence microscopy (Eclipse C600; Nikon). NIS Elements software was used to acquire images and analyze staining intensity. For quantification, slices were altas matched and those at the AP level of $\sim 1.20 \mathrm{~mm}$ from bregma were sampled. On each slice (two slices/rat), the mean intensity of two representative regions from core and two representative regions from shell was measured (as shown in Fig. 3D). The mean density of the anterior commissure was used for background subtraction. All images were taken with the same exposure time. To determine whether our results might have been affected by a change in the volume of the NAc in cocaine versus saline rats, we also measured the volume of NAc on WD45. After a fixation protocol similar to that described above, brain slices $(40 \mu \mathrm{m})$ were serially collected. Then every fourth section was selected, yielding a series of 8 equally spaced sections that spanned the NAc. The volume of the NAc was estimated according to Cavalieri principles (Coggeshall, 1992).

The same BDNF immunofluorescence protocol described above was used to verify expression of LV-BDNF-GFP 3 weeks after virus infusion into the NAc. BDNF immunoreactivity and GFP (expressed by the virus) were visualized by confocal microscopy (Fluoview; Olympus).

Biotinylation and protein crosslinking. For biotinylation, rats were decapitated at different withdrawal times (WD14, WD25, WD48, and WD90) after saline or cocaine self-administration training. Then NAc tissue from both hemispheres was collected and processed for biotinylation of surface-expressed proteins using sulfo-NHS-S-S-Biotin (Thermo Scientific). For each animal, a portion of biotinylated NAc tissue was set aside without further processing and used to measure total TrkB expression. The remainder of biotinylated tissue was purified using NeutrAvidin agarose beads (catalog no. 29204, Thermo Scientific), generating a bound fraction that was used to analyze TrkB surface expression. Both purified samples (bound fractions) and unprocessed samples were analyzed as described below (Western blotting). Biotinylation and purification methods have been described previously (Ferrario et al., 2011). For protein crosslinking, rats were decapitated $47 \mathrm{~d}$ after intracranial infusion of LV-GFP or LV-BDNF-GFP into either NAc core or shell. Then NAc core or shell subregions were dissected and processed for $\mathrm{BS}^{3}[$ bis(sulfosuccinimidyl)suberate] crosslinking as previously described (Boudreau and Wolf, 2005; Ferrario et al., 2010; Boudreau et al., 2012). The samples were further processed to distinguish surface and intracellular AMPAR subunits as described below (Western blotting).

RNA extraction and real-time PCR. Bilateral NAc core and shell tissue, as well as mPFC tissue, were collected separately $45 \mathrm{~d}$ after discontinuing either saline or cocaine self-administration. RNA was extracted with TRIzol reagent (15596-026, Invitrogen), according to the protocol from the manufacturer. After cleaning with the DNA-free Kit (AM1906, Invitrogen), $1 \mu \mathrm{g}$ of RNA from each sample was transcribed into cDNA using High-Capacity cDNA Reverse Transcription Kit (4368814, Applied Biosystems). To measure total BDNF mRNA levels and BDNF exon IV transcript levels, quantitative RT-PCR was performed using TaqMan Gene Expression Master Mix (4369016, Invitrogen) and normalized for each sample to the GAPDH mRNA levels. The primer and probe sets of TaqMan Gene Expression Assay for total BDNF and GAPDH were purchased from Applied Biosystems (total BDNF ID: Rn02531967_s1; GAPDH ID Rn01775763_g1). The BDNF exon IV-specific primer and probe set was made by TaqMan Custom Assay \& Oligo Service based on a previous study (Liu et al., 2006) measuring BDNF exon IV transcript levels. The 96-well plates with $25 \mu \mathrm{l}$ of reaction mixture in each well were first incubated at $50^{\circ} \mathrm{C}$ for $2 \mathrm{~min}$ and then at $95^{\circ} \mathrm{C}$ for another $10 \mathrm{~min}$, followed by 40 cycles $\left(95^{\circ} \mathrm{C}\right.$ for $10 \mathrm{~s}$ and then $60^{\circ} \mathrm{C}$ for $1 \mathrm{~min}$ ) of PCR. All samples were run in triplicate, and real-time fluorescence was detected by 7500 Real-time PCR System (Applied Biosystems). Threshold cycles $\left(\mathrm{C}_{\mathrm{t}}\right)$ were analyzed by 7500 System SDS Software (Applied Biosystems), and a relative quantification method $\left(\Delta \Delta C_{t}\right)$ was used to calculate target gene expression according to the Guide to Performing Relative Quantitation of Gene Expression Using Real-Time Quantitative PCR (Applied Biosystems).

Ampakine treatment. The regimen for ampakine treatment was taken from a previous study (Rex et al., 2006) in which rats received 2 intraperitoneal (i.p.) injections per day (one between 08:00 $\mathrm{h}$ and 09:00 $\mathrm{h}$; the other between 14:00 and 15:00 h) for 8 consecutive days. For the first $4 \mathrm{~d}$, all rats received vehicle injections [16.7\% 2-hydroxypropyl- $\beta$ cyclodextrin (H107, Sigma) in $0.9 \%$ sterile saline]. After this acclimatization period, rats in the vehicle group continued to receive vehicle injections for the next $4 \mathrm{~d}$, whereas rats in the ampakine group received injections of the ampakine CX929 (5 mg/kg dissolved in vehicle solution; provided by Cortex Pharmaceuticals). Twenty-two hours after the last injection, both NAc and hippocampal tissue from a randomly chosen hemisphere were dissected and homogenized in lysis buffer as previously described (Boudreau and Wolf, 2005) and processed as described below (Western blotting). NAc and hippocampal tissue from the other hemisphere were collected and processed for mRNA extraction, followed by RT-PCR to measure BDNF mRNA levels as described above (RNA extraction and real-time PCR). Rats were housed in pairs with one animal in the vehicle group and the other in the ampakine group.

Western blotting. All samples (10-20 $\mu$ g of per lane) were processed for Western blotting as previously described (Boudreau and Wolf, 2005; Ferrario et al., 2011; Boudreau et al., 2012) with the following primary antibodies: BDNF (sc-546, 1:500; Santa Cruz Biotechnology); phosphorylated TrkB (pTrkB, Tyr 706/707; 4621, 1:1000; Cell Signaling), TrkB (07-225, 1:2000; Millipore); GluA1 (PA1-37776, 1: 1000; Thermo Scientific); GluA2 (L21/32, 1:200; University of California Davis/National Institutes of Health NeuroMab Facility, Davis, California). After incubation with either HRP-conjugated anti-rabbit or anti-mouse IgG (1:10000; Invitrogen), proteins were visualized by film using the ECL detection system (GE Healthcare) and quantified by TotalLab (Life Sciences Analysis Essentials). GAPDH (CB1001, 1:10000; Calbiochem) was used as a loading control for BDNF, GluA1, and GluA2. The levels of pTrkB were normalized to TrkB levels, which were determined with the phosphorylation-independent TrkB antibody. The levels of TrkB in biotinylated samples (bound fraction) were normalized to total protein levels, which were determined with Ponceau-S stain (P7170, Sigma).

Statistical analysis. Unpaired $t$ tests (two-tailed) were conducted to compare mean values between two groups as indicated in each figure, except where otherwise noted. Two-way repeated-measure ANOVA with days $X$ virus pretreatment as factors was used to compare daily total infusions across the $10 \mathrm{~d}$ of cocaine self-administration training. Significance was set at $p<0.05$. 


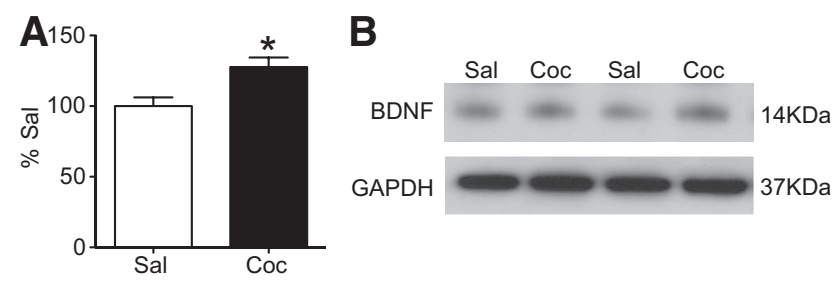

Figure 1. BDNF protein levels are increased in the NAC $45 \mathrm{~d}$ after discontinuing cocaine self-administration training. $\boldsymbol{A}$, Western blot analysis indicated a significant increase in BDNF protein levels $\left({ }^{*} p<0.05, t_{(13)}=3.015, t\right.$ test) in whole NAc of rats that self-administered cocaine ( $6 \mathrm{~h} / \mathrm{d}$ for $10 \mathrm{~d} ; n=8)$ compared with rats that self-administered saline ( $n=7)$. $\boldsymbol{B}$, Representative blots comparing cocaine and saline groups. Data (mean \pm SEM) are expressed as percentage of mean values in the saline group.

\section{Results \\ BDNF protein levels are increased in the NAc of cocaine rats on WD45}

We began by focusing on WD45, a time when incubation of cue-induced cocaine craving and synaptic accumulation of CP-AMPARs have been demonstrated in the rat NAc after extended access cocaine self-administration ( $6 \mathrm{~h} / \mathrm{d}$ for $10 \mathrm{~d}$ ) (Conrad et al., 2008). Immunoblotting was used to compare BDNF protein levels in NAc tissue obtained on WD45 after this same regimen of cocaine or saline self-administration. We found a significant increase in BDNF protein levels in the cocaine group (Fig. 1, $p<0.05$ ), consistent with a previous report showing increased BDNF levels on WD30 and an even greater increase on WD90 (Grimm et al., 2003). Selfadministration training data from the cocaine and saline rats shown in Figure 1 were published previously, as were biochemical results indicating increased levels of CP-AMPARs in the NAc of the cocaine group (Ferrario et al., 2011).

\section{Surface expression of phosphorylated TrkB is increased in cocaine rats on WD90}

The time-dependent increase in BDNF protein that occurs in the NAc during incubation (Grimm et al., 2003) (Fig. 1) could theoretically lead to time-dependent changes in TrkB expression or activation in the NAc. To test this, we used NAc tissue that was collected and biotinylated at different withdrawal time points (WD25, WD48, and WD90) after saline or cocaine selfadministration training using the same regimen described above. Then we measured surface and total levels of TrkB and phosphorylated TrkB (pTrkB; Tyr706/707) by immunoblotting. Phosphorylation at Tyr706/707 is necessary for TrkB activation and subsequent activation of downstream pathways (Segal et al., 1996; Cunningham et al., 1997; Huang and Reichardt, 2003). Although surface TrkB, total TrkB, and total $\mathrm{pTrkB}$ protein levels did not differ between cocaine and saline groups at any withdrawal time point (Fig. $2 B-D$ ), surface pTrkB levels were significantly elevated in the NAc of cocaine rats compared with saline controls by WD90 (Fig. $2 A, p<0.05$, one tail). This could indicate that gradual increases in BDNF signaling (Fig. 1; Grimm et al., 2003; also see Figs. 3 and 4) eventually lead to increased levels of TrkB activation during withdrawal.

\section{Time-dependent increases in BDNF levels follow different time courses in the NAc core versus shell}

Our studies of BDNF and TrkB described above (Figs. 1 and 2, respectively) were performed in whole NAc, rather than core and shell subregions, for two reasons. First, we were extending a prior study performed in whole NAc (Grimm et al., 2003). Second, our goal was to test a hypothesized link between BDNF and CPAMPAR accumulation during incubation, and we knew that CPAMPARs accumulated in both core and shell subregions of the NAc during incubation, although the effect is less robust in the shell (Conrad et al., 2008; McCutcheon et al., 2011). However, because previous evidence has suggested distinct BDNF-cocaine interactions in the NAc core versus shell (Graham et al., 2007; Graham et al., 2009), we next examined whether BDNF levels are differently affected in the NAc core and shell during incubation of cocaine craving.

As in prior studies, rats self-administered saline or cocaine for $6 \mathrm{~h} / \mathrm{d}$ for $10 \mathrm{~d}$ (Fig. 3A). They were killed on WD45, and brain sections were processed for BDNF immunohistochemistry. To quantify BDNF immunoreactivity in the NAc core and shell, we sampled two sections per animal. In each section, we measured the mean density of BDNF immunoreactivity in two regions of core and two regions of shell (Fig. $3 B$, squares). We observed a significant increase in BDNF staining in the NAc core of cocaine rats on WD45 ( $\sim 150 \%$ of saline control values; $p<0.05$ ), but no group difference in the NAc shell (Fig. $3 C, D$ ). Because core composes the majority of our whole NAc dissection, this explains the increased BDNF levels detected in whole NAc by immunoblotting in Figure 1. To determine whether BDNF levels eventually increase in the NAc shell, we prepared another cohort of rats and measured BDNF immunoreactivity in the NAc core and shell on WD90. At this withdrawal time, cocaine rats showed an even more robust increase in BDNF staining in the core $(\sim 270 \%$ of control) and now showed a significant increase in the shell $(\sim 180 \%$ of control) (Fig. $4 B, C$; $p<0.05$ ). In parallel with these studies, we compared the volume of the NAc in saline and cocaine rats (on WD45) and found no difference (Fig. $3 E$ ), indicating that our quantification of BDNF staining in the two groups was not influenced by volume changes. The different time courses of BDNF elevation in core and shell indicate that BDNF signaling in these subregions of the NAc may play different roles in the incubation of cocaine craving. Therefore, all subsequent experiments examined each subregion separately.

\section{BDNF mRNA levels are unchanged in the NAc core and shell on WD45}

BDNF mRNA is present in the NAc (Filip et al., 2006; Graham et al., 2007; Prakash et al., 2008), raising the possibility that the increased BDNF protein levels observed in the NAc during incubation could be the result of increased BDNF mRNA levels. To test this hypothesis, we used real-time PCR to measure BDNF mRNA levels in the NAc core and shell of cocaine and saline groups killed on WD45 after self-administration training. The training data are shown in Fig. 5A. Based on results in Figure 3, if increased BDNF protein is the result of increased BDNF mRNA levels, an increase in BDNF mRNA levels would be expected in core but not shell on WD45.

Multiple promoters of the BDNF gene as well as different transcriptional control mechanisms led to multiple BDNF transcripts. We first used a primer set that detects exon VIII, common to all BDNF transcripts (Liu et al., 2006), to measure total BDNF mRNA levels. We found no changes in either NAc subregion of cocaine rats compared with saline rats (Fig. 5B). Previous studies have shown that exon IV was selectively elevated both in the ventral striatum after acute cocaine exposure and in the mPFC $7 \mathrm{~d}$ after cocaine self-administration (Liu et al., 2006; Sadri-Vakili et al., 2010). In the mPFC, cocaine self-administration also increased the association of BDNF exon IV with acetylated histone H3 (Sadri-Vakili et al., 2010), which facilitates an open chroma- 
tin configuration and enhances gene transcription (Robison and Nestler, 2011). Moreover, methyl-CpG-binding protein 2 , a transcription factor that is a key regulator of BDNF gene expression (Chen et al., 2003; Martinowich et al., 2003; Im et al., 2010), showed decreased association with mPFC BDNF exon IV on WD7 after cocaine self-administration training (Sadri-Vakili et al., 2010). Based on these previous findings, we also measured BDNF exon IV expression in the NAc core and shell on WD45. However, similar to BDNF total mRNA, the level of BDNF exon IV did not differ between saline and cocaine groups (Fig. 5C). These data suggest that the cocaine-induced increase in BDNF protein is not the result of an increase in BDNF mRNA levels in the NAc. Although it remains possible that cocaine increased the translation of existing BDNF mRNA in NAc neurons, it is more likely that other mechanisms explain the increase in BDNF protein levels in the NAc after incubation (see Discussion).
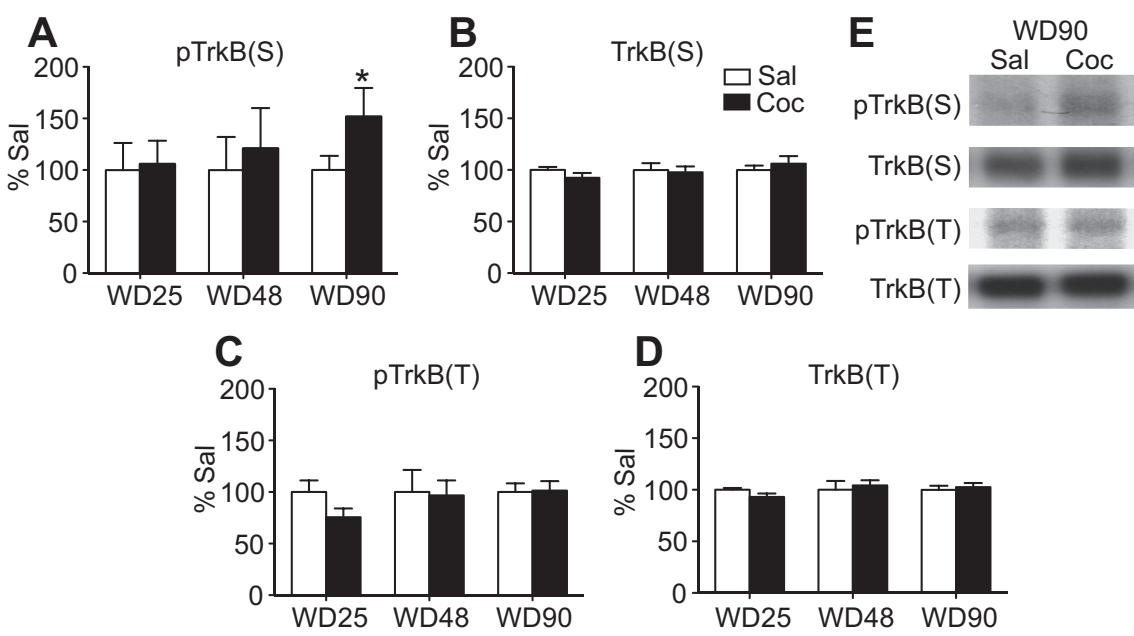

Figure 2. Cocaine self-administration leads to a significant increase in surface expression of phosphorylated TrkB (pTrkB; Tyr706/707) in whole NAC on WD90. $\boldsymbol{A}$, Whole NAc was obtained on WD25, WD48, or WD90 after saline or cocaine selfadministration and biotinylated. Surface-expressed pTrkB $[p \operatorname{TrkB}(S)]$ was significantly increased in the NAc of the cocaine group on WD90 (saline, $n=13$; cocaine, $n=8 ;{ }^{*} p<0.05, t_{(19)}=1.839, t$ test, one tail), whereas there were no differences between cocaine and saline groups on either WD25 (saline, $n=10$; cocaine, $n=9$ ) or WD48 (saline, $n=9$; cocaine, $n=10$ ). $\boldsymbol{B}-\boldsymbol{D}$, Surface $\operatorname{TrkB}[\operatorname{TrkB}(S)]$, total pTrkB $[\mathrm{pTrkB}(T)]$, and total $\operatorname{TrkB}[\operatorname{TrkB}(T)]$ in the cocaine group were similar to their respective saline controls at each withdrawal time. $\boldsymbol{E}$, Representative blots from WD90 groups are shown (TrkB: $140 \mathrm{kDa}$ ). Data (mean \pm SEM) are expressed as percentage of mean values in the saline group from the same WD.

\section{Attenuating BDNF-TrkB signaling in the NAc core before cocaine self-administration training enhances cocaine seeking on WD1}

To study whether BDNF-TrkB signaling in the NAc core plays a role in the incubation of cocaine craving, rats were infused with LV-TrkBsiRNA or LV-GFP (control) into the NAc core before cocaine self-administration training (Fig. 6A). Efficacy of this LV-TrKBsiRNA was previously demonstrated (Bahi et al., 2008; see also Materials and Methods). Two cohorts of rats were generated: one destined for a test of cue-induced cocaine seeking on WD1 (Cohort 1) and the other destined for testing on WD30 (Cohort 2). As shown in Figure 6B, cocaine infusions over $10 \mathrm{~d}$ of self-administration training did not differ between rats that received prior infusion of LV-GFP versus LV-TrkBsiRNA. However, cue-induced cocaine seeking on WD1 showed a $70 \%$ increase in LV-TrkBsiRNA rats compared with LV-GFP rats (Fig. $6 C, p<0.05)$. On WD30, LV-GFP rats showed incubation compared with WD1 (Fig. $6 C, p<0.05$ ), whereas LV-TrkB-siRNA rats showed only a trend $(p=0.11)$ toward a further increase compared with their elevated WD1 values. Thus, attenuating TrkB signaling in the NAc core before cocaine selfadministration enhanced cue-induced craving on WD1, suggesting that BDNF-TrkB signaling exerts a negative influence on cueinduced cocaine craving during early withdrawal.

Although LV-GFP rats and LV-TrkBsiRNA rats showed no significant difference in cue-induced cocaine seeking behavior on WD30 (Fig. 6C), BDNF protein levels in the NAc increase markedly between WD30 and WD90 (Grimm et al., 2003; Figs. 3 and 4) and incubation is maintained over this period (Grimm et al., 2001; Lu et al., 2004b; c). This suggests the possibility that elevation of BDNF levels may be important for a late phase of incubation, rather than its development during the first month after discontinuing cocaine self-administration. Indirect support for a relationship between $\mathrm{BDNF}$ and the persistence of incubation is provided by comparing the duration of incubation of cueinduced cocaine and sucrose seeking. Whereas incubation of cocaine seeking is at peak levels between WD30 and WD90 and is accompanied by increased BDNF levels, incubation of sucrose seeking in rats is much less persistent, returning to basal levels by WD90, and is not associated with increased BDNF levels in the NAc (Grimm et al., 2003; Lu et al., 2004c).

To test the hypothesis that elevation of BDNF levels may be important for the incubation at long withdrawal times, such as WD90, we used an AAV expressing a truncated form of TrkB (TrkB.T1) that acts as a dominant negative to attenuate BDNFTrkB signaling. This virus, referred to hereafter as AAV-TrkB.T1, has been shown to attenuate BDNF-TrkB signaling both in vivo and in vitro (Eisch et al., 2003; Wit et al., 2006; see Materials and Methods for more details). We used AAV-TrkB.T1 for two reasons. First, we had exhausted our supply of LV-TrkBsiRNA performing WD1/WD30 experiments in core (Fig. 6) and shell (see below). Furthermore, the FLAG or GFP tags on the AAVs provide a simple means of verifying that their expression lasts through WD90.

AAV-TrkB.T1 or AAV-GFP (control) was injected into the NAc core before cocaine self-administration training (Fig. $7 A$ ). In this experiment, the same rats (Cohort 3) were used to test cocaine seeking on WD1 and WD90. For our prior experiment (Fig. 6), we had used different cohorts on each test day, but we subsequently verified that 2 or 3 tests can be performed in the same animals without affecting incubation (data not shown), as also found previously (Lu et al., 2004a; Li et al., 2008; Lu et al., 2009). No difference in cocaine infusions was observed between AAV-TrkB.T1 and AAV-GFP groups during self-administration training (Fig. 7B). Consistent with results obtained using LVTrkBsiRNA to decrease BDNF-TrkB signaling in the NAc core (Fig. $6 C$ ), we observed a 70\% increase on $\mathrm{WD1}$ in rats previously infused with AAV-TrkB.T1 compared with AAV-GFP rats (Fig. $7 C, p<0.05)$. However, both AAV-GFP and AAV-TrkB.T1 rats showed incubation (significantly greater seeking on WD90 compared with WD1 within each group) and cocaine seeking on WD90 did not differ between the two groups (Fig. 7C), suggesting that knocking down BDNF-TrkB signaling in the NAc core did not affect this late phase of incubation of cocaine craving. The fact that TrKB.T1 rats exhibited incubation on WD90 relative to 
A

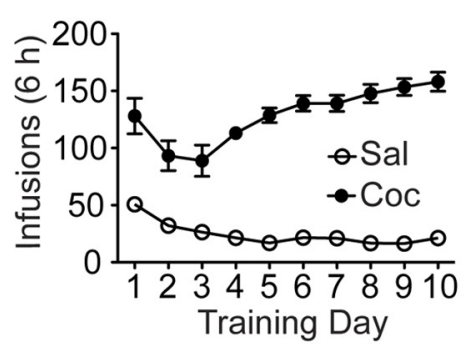

B

Bregma $1.20 \mathrm{~mm}$

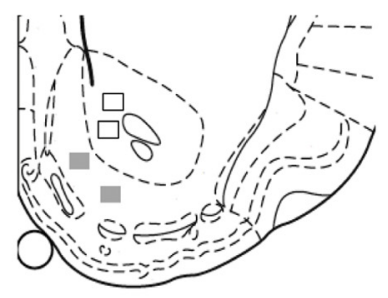

C

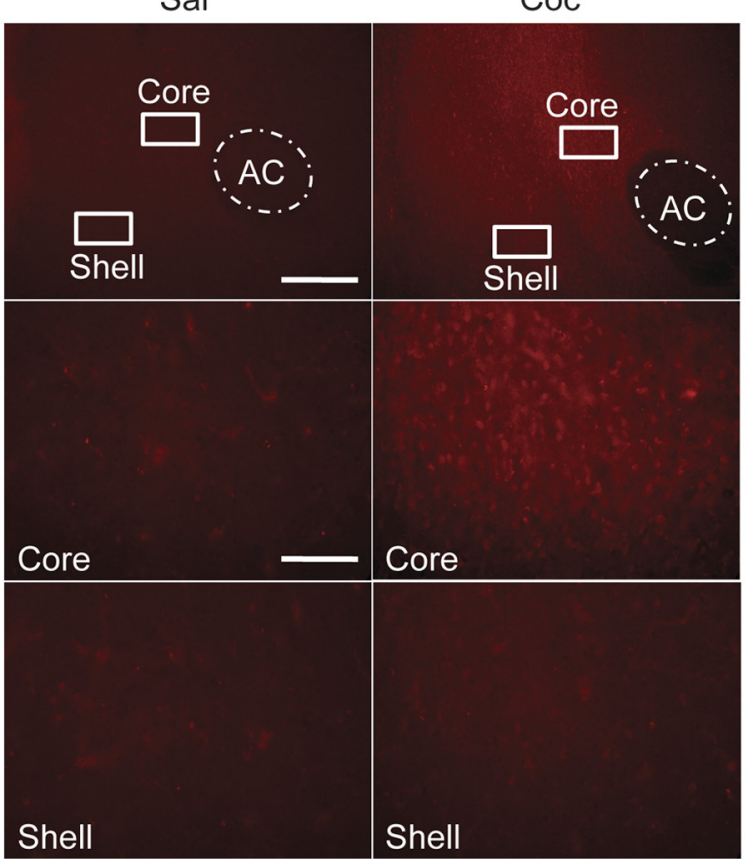

D

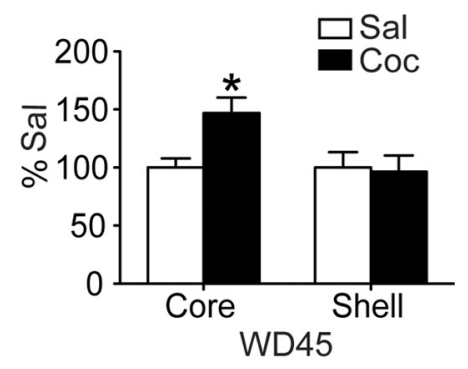

$\mathbf{E}$

NAc Volume

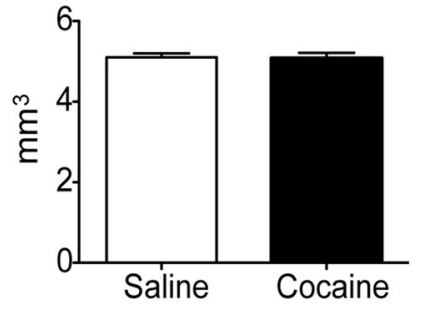

Figure 3. BDNF immunoreactivity is selectively increased in the NAc core on WD45 after cocaine self-administration training. $\boldsymbol{A}$, Infusions during $10 \mathrm{~d}$ of saline or cocaine self-administration training (saline, $n=13$; cocaine, $n=11$ ). $\boldsymbol{B}$, Schematic diagram illustrating regions sampled to measure BDNF immunoreactivity in NAc core (open boxes) and shell (closed gray boxes). $\boldsymbol{C}$, Representative images of BDNF staining in the NAc on WD45 after saline (left panels) or cocaine self-administration (right panels). Top, Low-magnification images. Scale bar, $1000 \mu \mathrm{m}$. Middle and bottom, Higher-magnification images in core and shell, respectively. Scale bar, $100 \mu \mathrm{m} . \boldsymbol{D}$, A significant increase in BDNF staining was observed in the NAc core $\left({ }^{*} p<0.05, t_{(22)}=3.117, t\right.$ test), but not shell, of the cocaine group on WD45 compared with the saline group. Data (mean \pm SEM) are expressed as percentage of mean values in the saline group. $\boldsymbol{E}$, The volume of the NAc (mm ${ }^{3}$ ) did not differ between saline and cocaine groups on WD45.

A

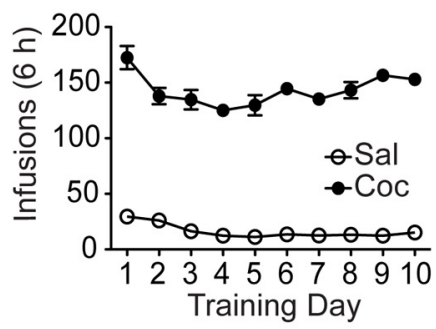

B

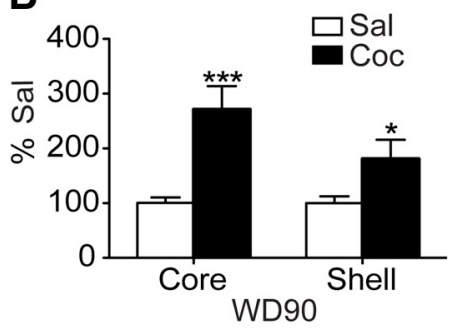

Sal
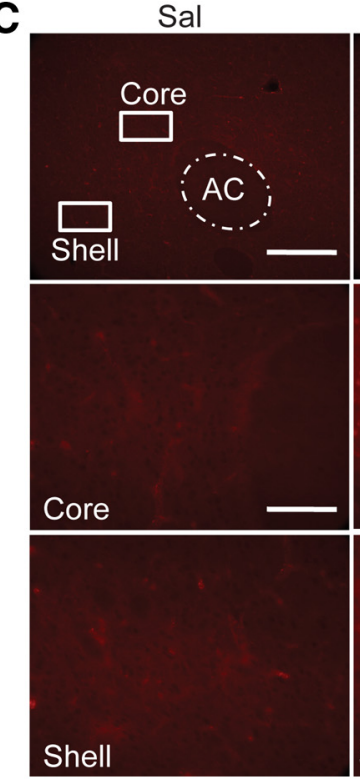

$\operatorname{Coc}$
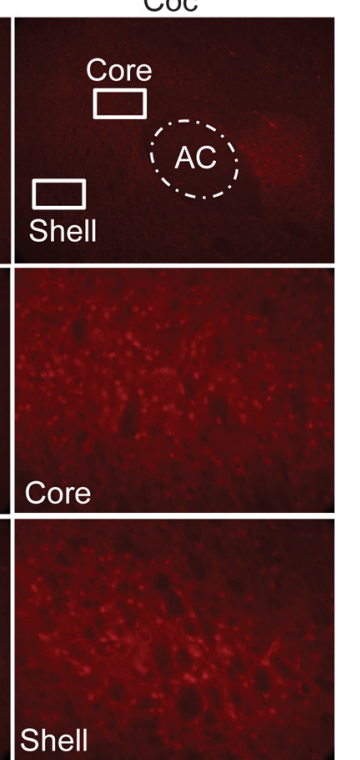

Figure 4. BDNF immunoreactivity is significantly elevated in both the NAc core and shell on WD90 after cocaine selfadministration training. $\boldsymbol{A}$, Infusions during $10 \mathrm{~d}$ of saline or cocaine self-administration training (saline, $n=12$; cocaine, $n=8$ ). $\boldsymbol{B}$, BDNF staining was significantly increased in the NAc core $\left({ }^{* * *} p<0.0005, t_{(15)}=5.070, t\right.$ test; saline, $n=11 ;$ cocaine, $\left.n=6\right)$ and shell $\left({ }^{*} p<0.05, t_{(18)}=2.537, t\right.$ test; saline, $n=12$; cocaine, $\left.n=8\right)$ in the cocaine group on WD90 compared with saline controls. Data (mean \pm SEM) are expressed as percentage of mean values in the saline group. $C$, Representative images of BDNF staining in the NAc on WD90 after saline (left) or cocaine self-administration (right). Top, Low-magnification images. Scale bar, $1000 \mu \mathrm{m}$. Middle and bottom, Higher-magnification images in core and shell, respectively. Scale bar, $100 \mu \mathrm{m}$.

WD1 in this experiment, but not on WD30 relative to WD1 in the experiment shown in Figure 6, most likely reflects the longer duration of the former experiment, permitting a difference to emerge relative to WD1. After the WD90 test, we assessed expres- sion of AAV-TrkB.T1 by FLAG immunohistochemistry. As shown in Figure $7 D$, strong FLAG signals were observed in the NAc core, indicating that the virus was still expressing on WD90. Together, our behavioral results suggest that basal levels of BDNF signaling in the NAc core (i.e., levels present before the withdrawaldependent increase in BDNF protein) exert a suppressive effect on cue-induced cocaine seeking on WD1 because attenuating BDNF-TrkB signaling using either LV-TrkBsiRNA or AAV-TrkB.T1 enhanced cocaine seeking in WD1 tests.

\section{Attenuating BDNF-TrkB signaling in the NAc shell before cocaine self-administration training suppresses cocaine seeking on WD90}

Next, we studied whether BDNF in the NAc shell also plays a role in the incubation of cocaine craving by using similar viral vectors to attenuate BDNF-TrkB signaling. First, rats received intracranial infusion of LV-GFP, LV-TrkBsiRNA, or LV-TrkB.T1 into the NAc shell and then were trained to self-administer cocaine for $10 \mathrm{~d}$ (Fig. 8A). Previous work showed similar behavioral effects regardless of whether BDNF-TrkB signaling was attenuated by injection of LV-TrkBsiRNA or LV-TrkB.T1 into the NAc (Bahi et al., 2008). Cue-induced cocaine seeking behavior was tested on WD1 and 
WD45. Similar to the lentivirus experiments in the core, we used different cohorts of rats for each WD (Cohort 4, WD1; Cohort 5, WD45). Viral injection into the NAc shell before cocaine selfadministration training did not affect responding of the rats during training (Fig. $8 B)$. Results of WD1 and WD45 tests indicated that all three groups exhibited incubation of cocaine craving (within group comparisons of WD1 and WD45), and no differences were observed between the three groups on either WD1 or WD45 (Fig. $8 C, p<0.05$ ).

To determine whether BDNF in the NAc shell is involved in a late phase of incubation, we tested cocaine seeking on WD90 after knocking down BDNF-TrkB signaling in the NAc shell using AAVTrkB.T1 (Fig. 9A). Consistent with previous results obtained using LVTrkBsiRNA and LV-TrkB.T1 (Fig. 8C), no difference was found on WD1. However, a significant decrease $(\sim 30 \%)$ of cueinduced seeking was observed in AAVTrkB.T1 rats compared with AAV-GFP rats on WD90 (Fig. 9C, $p<0.5$ ), although both groups of rats showed incubation compared with their responding on WD1. Virus expression was verified after the WD90 test by FLAG or GFP immunohistochemistry (Fig. 9D). These results indicate that BDNF-TrkB signaling in the NAc shell is required to achieve maximal levels of incubation during prolonged withdrawal.

\section{Long-term elevation of BDNF in the NAc core or shell is not sufficient to increase CP-AMPAR expression}

Our laboratory has previously shown that

the expression of incubation of cocaine craving on WD45, after the same cocaine self-administration regimen used here, is mediated by GluA1-containing CP-AMPARs that accumulate in the NAc during withdrawal (Conrad et al., 2008). As noted in the Introduction, there is evidence that BDNF can promote synaptic delivery of CP-AMPARs in the NAc core of adult drugnaive rats (Li and Wolf, 2011a) and in vitro preparations from other brain regions (Caldeira et al., 2007; Li and Keifer, 2008; Li and Keifer, 2009; Keifer and Zheng, 2010; Fortin et al., 2012). These results led us to hypothesize that elevation of BDNF levels in the NAc might underlie the accumulation of CP-AMPARs during cocaine withdrawal. To test this hypothesis, we used LVBDNF-GFP to overexpress BDNF in the NAc core or shell in drug-naive rats and studied AMPAR expression and distribution using a $\mathrm{BS}^{3}$ protein crosslinking assay. As the LV-BDNF-GFP virus has not been previously studied, we first verified viral expression in vivo using BDNF immunohistochemistry. As shown in Figure $10 \mathrm{~A}$, neurons expressing GFP immunoreactivity also showed intense staining for BDNF. Next, we studied the effect of long-term BDNF overexpression in the NAc core or shell on AMPAR subunit surface expression. An increase in surface expression of
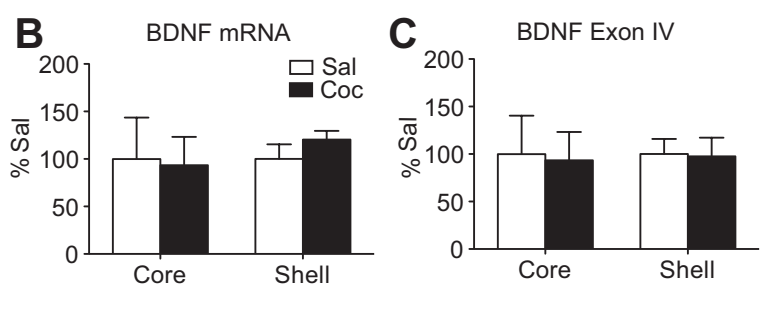

Figure 5. Neither total BDNF mRNA nor BDNF exon IV levels are increased in the NAc $45 \mathrm{~d}$ after discontinuing cocaine selfdministered saline $(n=9)$ or cocaine $(n=8)$. $\boldsymbol{B}, \boldsymbol{C}$, Real-time $P C$ R analysis revealed no differences in total BDNF mRNA expression or BDNF exon IV levels in either NAc core or shell of the cocaine group compared with the saline group on WD45. Data (mean \pm
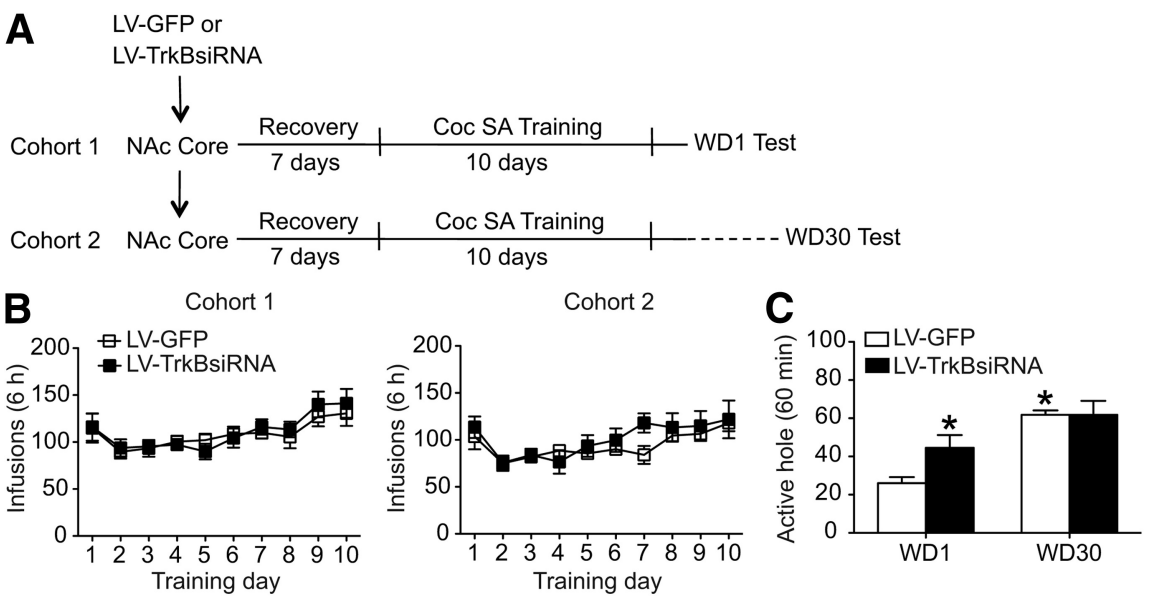

Figure 6. Attenuating BDNF-TrkB signaling with LV-TrkBsiRNA in the NAc core led to enhanced cue-induced cocaine seeking on 0.05, $t_{(11)}=2.576, t$ test; LV-GFP, $n=7 ;$ LV-TrkBsiRNA, $\left.n=6\right)$. By WD30, no difference was apparent between the LV-GFP and 列 previously active hole during a 60 min cocaine-seeking test in which cocaine was not available and each nose-poke into the active hole resulted in the delivery of the light cue previously paired with cocaine infusions.

GluA1 in the absence of a change in GluA2 would be suggestive of elevated CP-AMPAR levels (e.g., Conrad et al., 2008; Li and Wolf, 2011a). However, $47 \mathrm{~d}$ after infusion of LV-BDNF-GFP into NAc core or shell, both GluA1 and GluA2 surface expression were unchanged compared with LV-GFP rats (Fig. $10 B, C, p<0.05$ ). The postinfusion time point $(47 \mathrm{~d}$ ) was chosen because it corresponds to a withdrawal time when both BDNF and CP-AMPAR levels are elevated in the NAc core during the incubation of cocaine craving (Grimm et al., 2003; Conrad et al., 2008; Wolf and Tseng, 2012).

Together, our results show that long-term overexpression of BDNF in the NAc is not sufficient to increase CP-AMPAR surface expression. This argues against our original hypothesis that cocaine-induced elevation of BDNF is responsible for the increase in CP-AMPARs. Also arguing against this hypothesis is our finding that BDNF levels in the shell subregion are not yet elevated on WD45 (Fig. 3), despite the fact that CPAMPARs can be detected in the shell at similar withdrawal times (McCutcheon et al., 2011). However, it remains possible that viral mediated overexpression of BDNF does not reproduce the spatial and/or temporal pattern of the cocaine- 


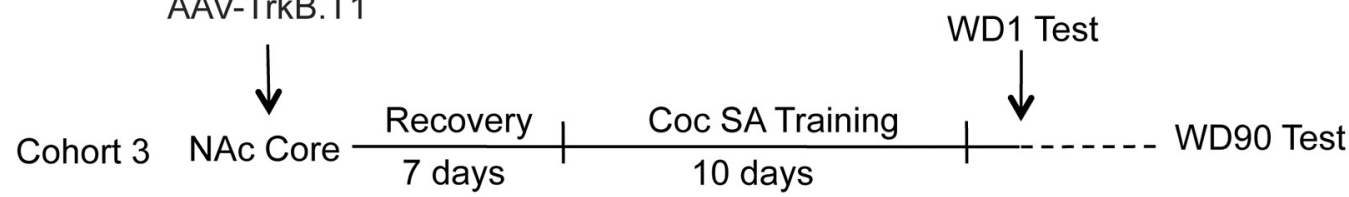

B

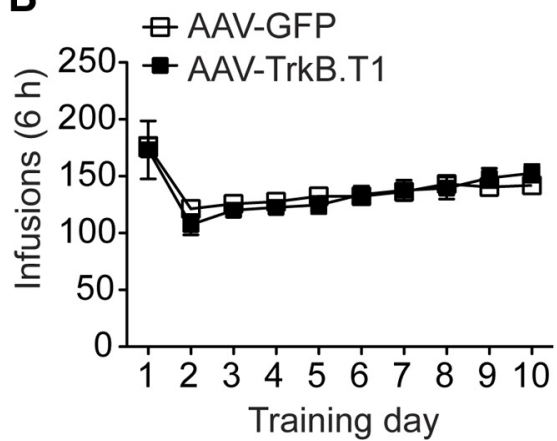

C

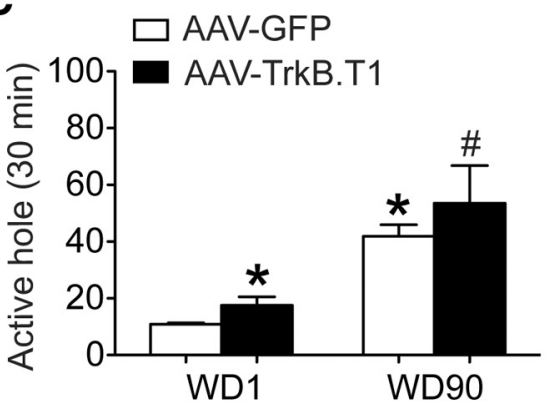

D

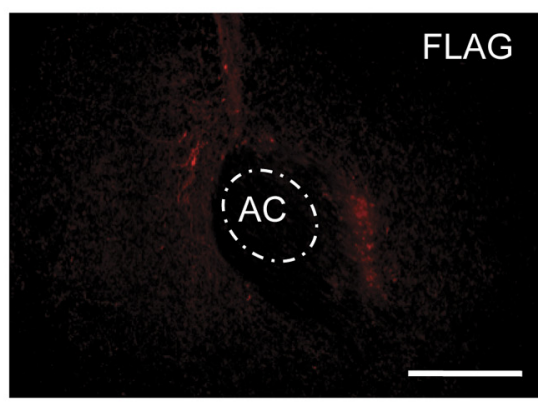

Figure 7. Attenuating BDNF-TrkB signaling with AAV-TrkB.T1 in the NAc core led to enhanced cue-induced cocaine seeking on WD1. $\boldsymbol{A}$, Experimental timeline. $\boldsymbol{B}$, Cocaine self-administration training was similar between AAV-GFP $(n=7)$ and AAV-TrkB.T1 $(n=6)$ groups. C, Similarly to results obtained with LV-TrkBsiRNA (Fig. 6), we observed significantly enhanced cue-induced cocaine seeking on WD1 in the AAV-TrkB.T1 group compared with the AAV-GFP group $\left({ }^{*} p<0.05, t_{(11)}=2.357, t\right.$ test). No difference was found between the groups on WD90, but both groups showed incubation compared with their respective WD1 (AAV-GFP: ${ }^{*} p<0.05, t_{(6)}=7.704$; AAV-TrkB.T1: ${ }^{\#} p<0.05, t_{(5)}=2.326$; one tailed, paired $t$ tests). Results are expressed as nose-pokes (mean \pm SEM) in the previously active hole during a 30 min cocaine-seeking test conducted as described in the legend to Figure $6 . \boldsymbol{D}$, Representative image showing FLAG immunostaining in the NAc core after the final seeking test on WD90. Scale bar, $1000 \mu \mathrm{m}$.

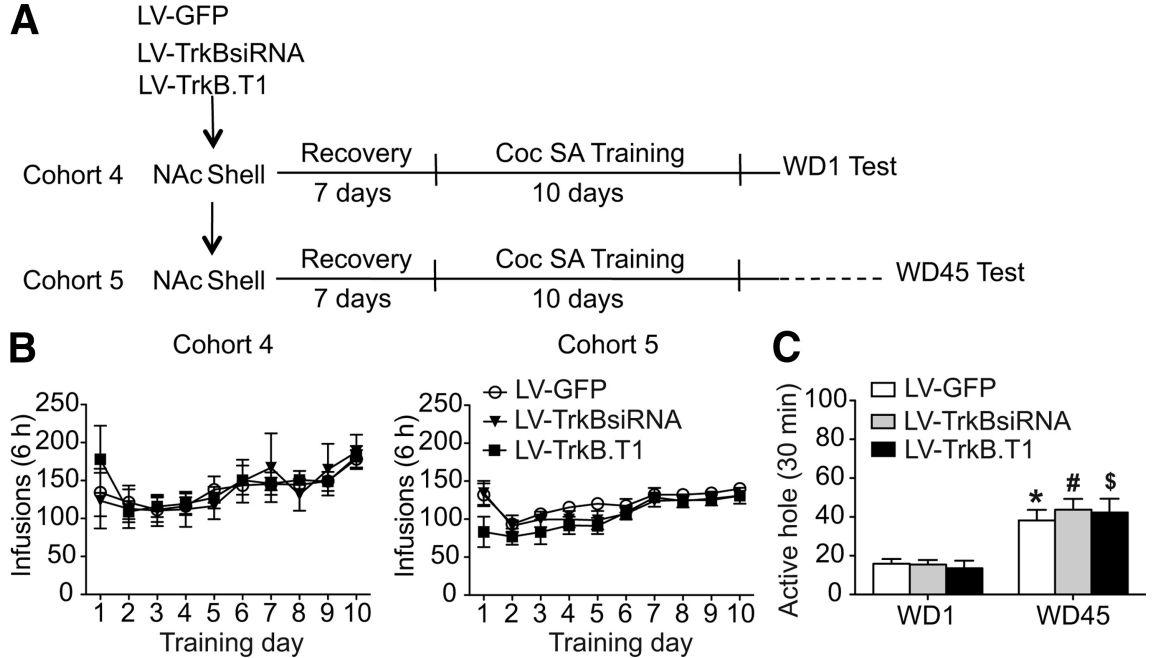

Figure 8. Attenuating BDNF-TrkB signaling with LV-TrkBsiRNA or LV-TrkB.T1 in the NAc shell had no effect on cue-induced cocaine seeking on either WD1 or WD45. $\boldsymbol{A}$, Experimental timeline. $\boldsymbol{B}$, Cocaine self-administration training was similar in both cohorts, and no differences were found between LV-GFP, LV-TrkBsiRNA, and LV-TrkB.T1 groups. C, No effects on cue-induced cocaine seeking were observed on either WD1 or WD45 in rats injected with LV-GFP, LV-TrkBsiRNA, or LV-TrkB.T1 in the NAc shell before cocaine self-administration training, although all three WD45 groups (LV-GFP: $n=9$; LV-TrkBsiRNA: $n=9$; LV-TrkB.T1: $n=6$ ) showed incubation compared with respective WD1 groups (LV-GFP: $n=9$; LV-TrkBsiRNA: $n=9 ;$ LV-TrkB.T1: $n=7$ ). Comparison of WD1 and WD45 groups: LV-GFP, ${ }^{*} p<0.05, t_{(16)}=3.758 ;$ LV-TrkBsiRNA, ${ }^{\#} p<0.05, t_{(16)}=4.617$; LV-TrkB.T1, ${ }^{\$} p<0.05, t_{(11)}=3.716 ; t$ tests. Results are expressed as nose-pokes (mean $\pm \mathrm{SEM}$ ) in the previously active hole during a $30 \mathrm{~min}$ cocaine-seeking test conducted as described in the legend to Figure 6.

induced elevation in endogenous BDNF during incubation. For example, anterograde transport of BDNF from particular brain regions may lead to a specific pattern of BDNF-TrkB signaling, which is required to influence GluA surface expression. It is also possible that elevation of BDNF is involved in CP-AMPAR expression but is not sufficient, i.e., other cocaine-induced adaptations are also necessary.
Ampakine treatment increases BDNF protein expression in the NAc

Ampakines, positive modulators of AMPAR transmission that work by slowing deactivation and desensitization of AMPARs (Lynch and Gall, 2006), have been shown to increase BDNF protein levels in cultured hippocampus neurons as well in rat hippocampus in vivo (Lauterborn et al., 2000; 2003; Rex et al., 2006; Lauterborn et al., 2009). This led us to consider a novel hypothesis for the relationship between BDNF and CP-AMPARs during incubation. Rather than proposing that BDNF mediates the increase in $\mathrm{CP}$ AMPARs observed during incubation, we wondered whether enhanced AMPAR transmission after prolonged withdrawal (due to high conductance CP-AMPAR accumulation) contributes to the time-dependent increase in BDNFlevels in the NAc. As a first step toward exploring this hypothesis, we conducted a proof-of-principle study aimed at determining whether enhancing AMPAR transmission, using ampakines, increases BDNF expression in NAc of drug-naive rats.

Rats were treated with the ampakine CX929 (5 mg/kg, i.p.) using a repeated injection regimen previously shown to increase BDNF levels in the rat hippocampus (Rex et al., 2006). Consistent with their results, we observed a significant increase in BDNF protein levels in hippocampus after ampakine treatment (Fig. 11, $p<0.05$ ). BDNF protein was also significantly elevated in the NAc (Fig. 11), supporting our hypothesis. Using tissue from the same animals, we failed to detect an increase in BDNF 
$\downarrow$

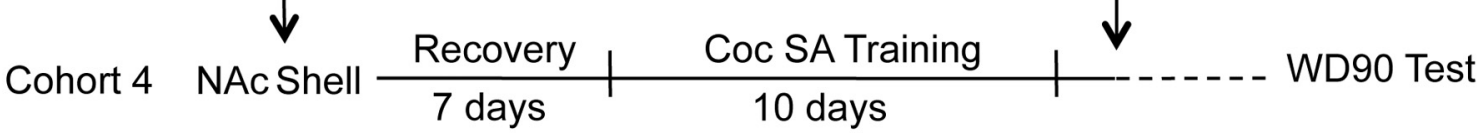

B

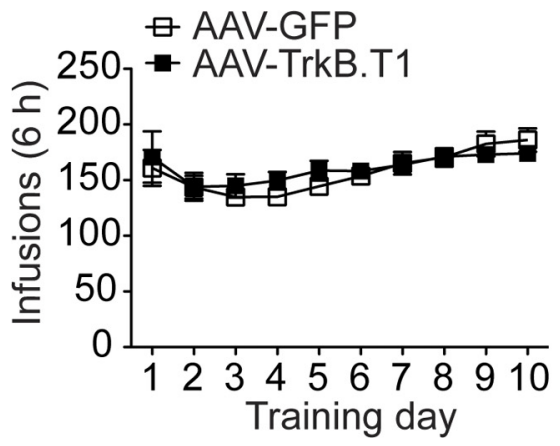

C

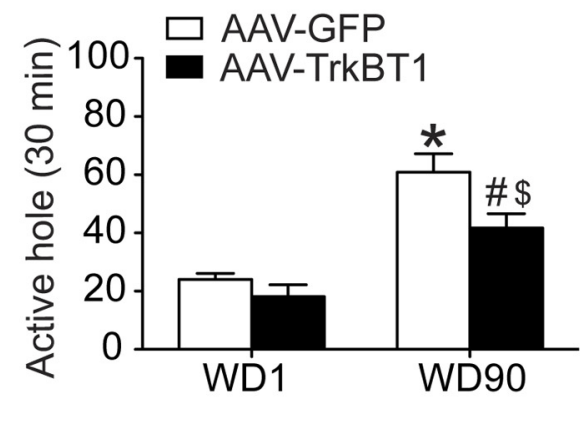

D

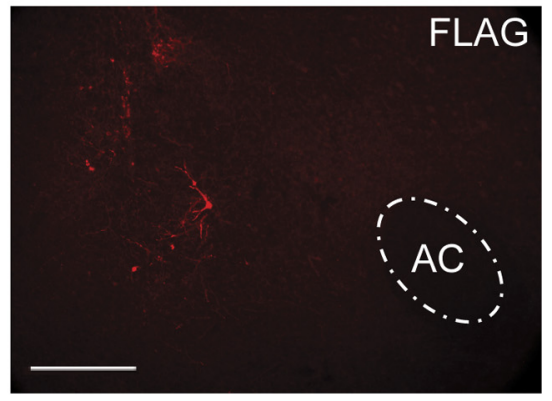

Figure 9. Attenuating BDNF-TrkB signaling with AAV-TrkB.T1 in the NAc shell led to significantly decreased cue-induced cocaine seeking on WD90. $\boldsymbol{A}$, Experimental timeline. $\boldsymbol{B}$, Cocaine self-administration training was similar for AAV-GFP $(n=7)$ and AAV-TrkB.T1 $(n=6)$ groups. $C$, On WD1, there was no difference in cue-induced cocaine seeking between AAV-GFP and AAV-TrkB.T1 groups. On WD90, although both groups showed incubation compared with their respective WD1 (AAV-GFP: ${ }^{*} p<0.05, t_{(6)}=7.017 ;$ AAV-TrkB.T1: $^{\#} p<0.05, t_{(5)}=4.437 ;$ paired $t$ tests), the response of the AAV-TrkB.T1 group was significantly decreased compared with the AAV-GFP group $\left({ }^{\$} p<0.05, t_{(11)}=2.333, t\right.$ test). $\boldsymbol{D}$, Representative image showing FLAG immunostaining in NAc shell after the behavioral test on WD90. Scale bar, $1000 \mu \mathrm{m}$.

mRNA levels in either hippocampus (data not shown) or NAc (Fig. 11) after ampakine treatment. This was not surprising, as prior studies have shown that BDNF protein and $\mathrm{mRNA}$ levels in hippocampus do not always show parallel alterations after ampakine treatment (Lauterborn et al., 2000).

An alternative to the ampakine hypothesis is that BDNF protein levels increase in the NAc during incubation as a result of anterograde transport from another brain region. The $\mathrm{mPFC}$ is one candidate, based on a report that BDNF levels increase in the MPFC after limited access cocaine self-administration and $7 \mathrm{~d}$ of withdrawal (Sadri-Vakili et al., 2010). We therefore measured BDNF protein levels in $\mathrm{mPFC}$ on WD45, using tissue obtained previously after the same cocaine or saline self-administration regimen used herein. We also measured BDNF mRNA in MPFC tissue obtained from the same saline and cocaine rats used to measure BDNF mRNA levels in the NAc on WD45 (Fig. 5). No differences were found between groups for mPFC levels of BDNF protein [data normalized to saline controls; saline, $100 \pm 9.1 \%(n=9)$; cocaine, $99.4 \pm 3.5 \%(n=6) ; p>0.05]$ or BDNF mRNA [ saline, $100.0 \pm 7.4 \%(n=9)$; cocaine, $99.7 \pm$ $7.7 \%(n=8) ; p>0.05]$.

\section{Discussion}

We investigated the role of BDNF-TrkB signaling in the incubation of cocaine craving, as well as BDNF's role in the CP-AMPAR accumulation that accompanies incubation. Levels of BDNF pro-
A

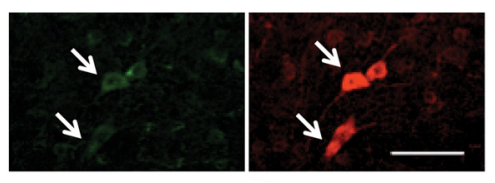

B Core

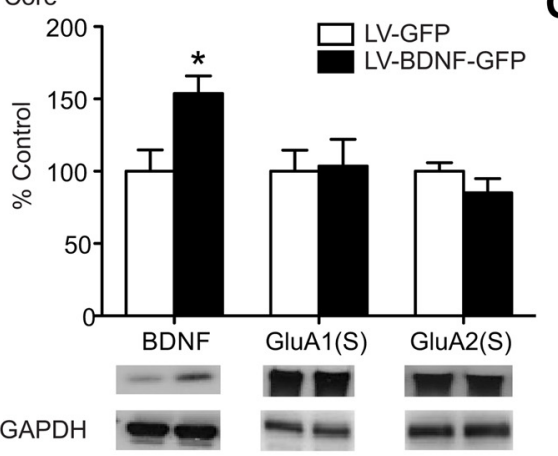

C Shell

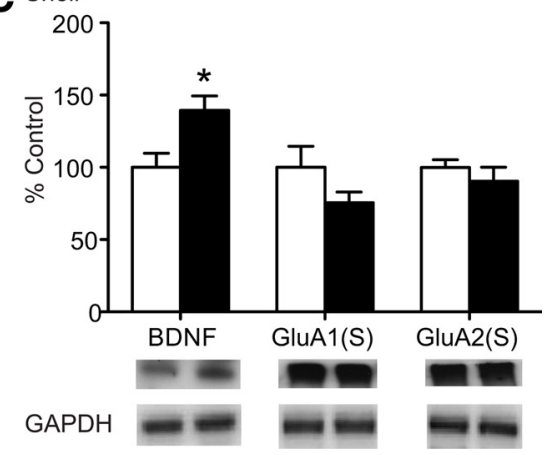

Figure 10. Long-term elevation of BDNF levels with LV-BDNF-GFP had no effect on GluA1 or GluA2 surface expression in either the NAc core or shell. $\boldsymbol{A}$, Representative image of BDNF staining 3 weeks after injection of LV-BDNF-GFP into the NAc core. Intense staining for BDNF (red) was observed in infected neurons, identified based on GFP expression (green). Note that the GFP signal is weak because it was not amplified by immunostaining. These results demonstrate that LV-BDNF-GFP was effective in vivo. Scale bar, $100 \mu \mathrm{m}$. B , Forty-seven days after injection of LV-GFP $(n=9)$ or LV-BDNF-GFP $(n=4)$ into the NAc core, BDNF levels in the core of the LV-BDNF-GFP group were significantly elevated compared with LV-GFP controls ( ${ }^{*} p<0.05, t_{(11)}=2.242$, $t$ test), but this chronic elevation of BDNF levels failed to affect GluA1 and GluA2 surface expression. C, Similarly, whereas BDNF levels in the shell of the LV-BDNF-GFP group $(n=8)$ showed a significant increase compared with the LV-GFP group $\left(n=11\right.$; ${ }^{*} p<0.05$, $t_{(17)}=2.750, t$ test), no changes on GluA1 and GluA2 surface expression were observed. Data (mean \pm SEM) are expressed as percentage of mean values in the LV-GFP group.

tein, but not mRNA, were increased in whole NAc on WD45. In studies distinguishing core from shell, we found that BDNF increased first in the core (WD45). However, BDNF was further elevated in the core and also elevated in the shell on WD90, a time point at which cell surface $\mathrm{p}$ TrkB was also significantly increased in whole NAc. Behavioral studies using viral vectors showed that attenuating BDNF-TrkB signaling in core before cocaine selfadministration training enhanced cocaine seeking during early 


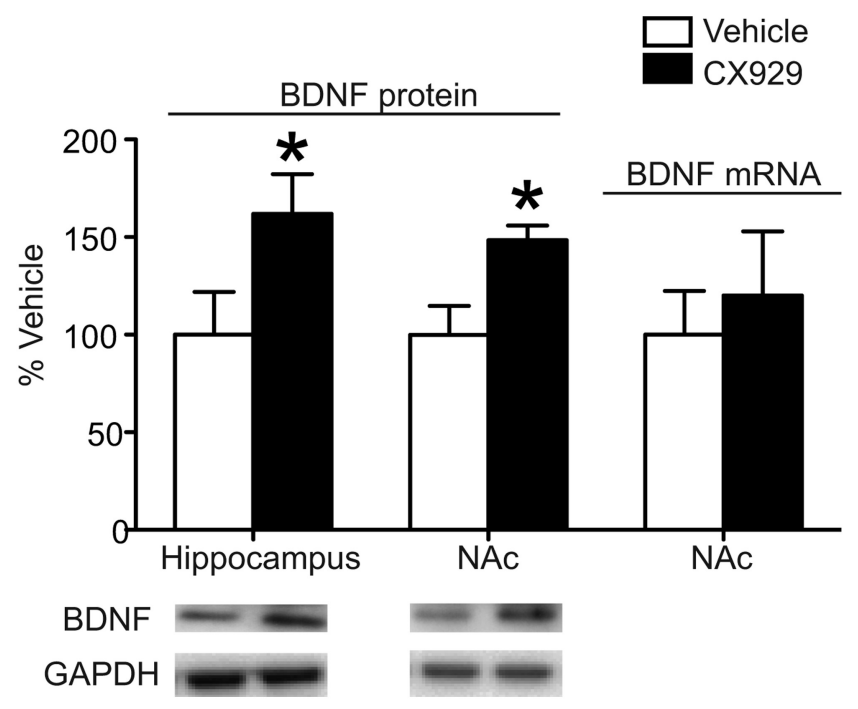

Figure 11. Treatment with the ampakine CX929 in drug naive rats significantly increased BDNF protein levels in whole NAc. As a positive control, we first confirmed that BDNF protein levels in rat hippocampus were significantly elevated in the ampakine treatment group $(n=8)$ compared with the vehicle group $(n=8)\left({ }^{*} p=0.05, t_{(7)}=2.506\right.$, paired $t$ test), consistent with previous studies (Rex et al., 2006). Analysis of whole NAc from the same animals revealed elevated BDNF protein levels ( ${ }^{*} p<0.05, t_{(7)}=2.328$, paired $t$ test) but no change in BDNF total mRNA levels. Data (mean \pm SEM) are expressed as percentage of mean values in the vehicle group.

withdrawal (WD1), whereas similar attenuation in shell suppressed cocaine seeking after prolonged withdrawal (WD90). Finally, in studies designed to explore the relationship between BDNF and CP-AMPAR plasticity, we found no evidence of increased CP-AMPAR surface expression after chronic elevation of BDNF levels in core or shell. However, enhancing AMPAR transmission with an ampakine increased NAc BDNF levels.

\section{Possible mechanisms underlying increased BDNF protein levels during incubation}

Although cocaine exposure can increase BDNF mRNA in the NAc (Le Foll et al., 2005; Filip et al., 2006; Fumagalli et al., 2007; Graham et al., 2007; Huang et al., 2011), our results show that BDNF protein levels in the NAc increase during incubation in the absence of changes in mRNA levels. Dissociation between cocaine's effects on BDNF mRNA and protein levels has been reported previously (Fumagalli et al., 2007). We also failed to detect changes in BDNF exon IV levels, which are altered after other cocaine regimens (Liu et al., 2006; Sadri-Vakili et al., 2010). These results suggest that mechanisms other than increased mRNA levels must explain increased BDNF protein during incubation. One possibility is anterograde transport from regions, such as the mPFC or VTA, which project to NAc and express high BDNF levels (Altar et al., 1997; Conner et al., 1997; Altar and DiStefano, 1998; Lessmann et al., 2003). To address this, we measured BDNF mRNA and protein in MPFC on WD45 after cocaine selfadministration and failed to find any difference between saline and cocaine groups. This argues against anterograde transport from $\mathrm{mPFC}$ but does not rule out transport from other regions, most notably the VTA, in which BDNF has been implicated in incubation of cocaine craving (Grimm et al., 2003; Lu et al., 2004a). However, additional possibilities exist. Translation of existing BDNF mRNA in the NAc could be enhanced (e.g., resulting from changes in abundance of long 3'UTR BDNF mRNA) (Lau et al., 2010). In addition, BDNF mRNA can be stabilized by $\mathrm{Ca}^{2+}$ influx (Fukuchi et al., 2005), and $\mathrm{Ca}^{2+}$ influx should be increased once CP-AMPARs are in the synapse. Finally, processing of proBDNF into mature BDNF can also be increased in a $\mathrm{Ca}^{2+}$ dependent manner (Gualandris et al., 1996).

\section{Activation of TrkB receptors in the NAc after prolonged withdrawal}

Prolonged exposure to BDNF leads to downregulation of TrkB receptors in vitro (Sommerfeld et al., 2000), making us wonder whether TrkB receptor expression in the NAc changes in response to BDNF elevation during incubation. By biotinylating NAc tissue at different withdrawal times, we found no difference between cocaine and saline groups in cell surface or total levels of TrkB or pTrkB (Thr 706/606; phosphorylation at this site reflects TrkB activation) in whole NAc on WD25 and WD48, even though BDNF levels are increased in the core by WD45. However, cell surface pTrkB was increased on WD90, the time when BDNF levels in core are further elevated and BDNF elevation in shell is also observed. The reason for the delay in increased surface expression of $\mathrm{pTrkB}$ is unclear. However, the rate of BDNF application affects subsequent signaling (Ji et al., 2010). A gradual increase in endogenous BDNF during incubation may elicit a slow activation of TrkB (contrasting with rapid activation after acute exogenous BDNF application; Li and Wolf, 2011a). It should be noted that we did not measure TrkB in core and shell separately, but other results indicate the possibility of different TrkB regulation in these subregions (Toda et al., 2002; Graham et al., 2007; Graham et al., 2009).

Core-shell differences in the role of BDNF during incubation As discussed above, BDNF levels increase first in the core and later in shell during incubation, adding to evidence that cocaine differently affects BDNF expression in core versus shell (Filip et al., 2006; Graham et al., 2007; Huang et al., 2011). Before our work, however, it was unclear whether BDNF in core and shell contribute differently to cocaine seeking. Graham et al. (2007) showed that daily delivery of BDNF into the shell facilitated cocaine reward after 11-15 d of withdrawal from cocaine self-administration, whereas delivery of BDNF blocking-antibody produced the opposite effect. Although analogous studies in the core were not performed, a series of studies provide indirect support for an opposite effect of BDNF in core (Berglind et al., 2007, 2009; Whitfield et al., 2011). They showed that intra-PFC infusion of BDNF, immediately after completion of cocaine self-administration training, suppressed cocaine seeking $22 \mathrm{~h}$ later. This depended on TrkB activation in the mPFC. However, BDNF levels in NAc were also elevated (presumably through anterograde transport) and cocaine-induced adaptations in the NAc were normalized. These studies did not distinguish core from shell. However, the dorsomedial region of PFC injected with BDNF projects primarily to the core (Pierce et al., 1998). Thus, the intra-PFC infusion of BDNF may have elevated BDNF predominantly in core, and this may have contributed to the ability of intra-PFC BDNF to suppress cocaine seeking.

To investigate the possibility that BDNF in core and shell play opposite roles in incubation of cocaine seeking, we used viral vectors to attenuate BDNF-TrkB signaling before cocaine self-administration. When BDNF-TrkB signaling was attenuated in the core, we observed enhanced seeking on WD1, but no difference from controls at later withdrawal times (WD30 or WD90). Because the cocaine-induced increase in endogenous BDNF does not occur until well after WD1 (Grimm et al., 
2003), these results suggest that basal levels of BDNF transmission in the NAc core normally exert a suppressive effect on cue-induced cocaine seeking during early withdrawal. The direction of the effect is consistent with our interpretation of the results of intra-PFC BDNF infusion mentioned above (Berglind et al., 2007). On the other hand, after attenuation of BDNF-TrkB signaling in shell, cue-induced cocaine seeking was unaltered on WD1 or WD30 but significantly attenuated on WD90, the same withdrawal time at which we observed elevated BDNF levels in the shell. Indeed, in rats treated to knock down TrkB signaling in the shell, the level of responding on WD90 (Fig. 9C) was very similar to that observed on WD45 (Fig. $8 C$ ), supporting the idea that attenuation of BDNF-TrkB signaling in the NAc shell prevents the enhancement of responding that normally occurs between WD45 and WD90. Together, these results suggest that withdrawal-dependent elevation of BDNF-TrkB signaling in the NAc shell contributes to incubation during late withdrawal. This is consistent with evidence that BDNF in the shell facilitates cocaine seeking (Graham et al., 2007), although different cocaine regimens preclude a direct comparison. To our knowledge, our study is the first to investigate the role of endogenous BDNF in core versus shell during incubation. Our results suggest that BDNF's role is not only distinct in these subregions, but also in different timeframes during withdrawal. Adding to the complexity, BDNF levels also increase in dorsal striatum during extended access cocaine self-administration, promoting cocaine seeking (Im et al., 2010).

\section{Possible relationship between BDNF and CP-AMPARs during incubation}

Using a protein crosslinking assay, we found that chronic BDNF elevation using viral vectors failed to affect GluA1 surface expression in the NAc. Because CP-AMPARs accumulating during incubation are largely homomeric GluA1 (Conrad et al., 2008), this suggests that increased BDNF levels during incubation are not sufficient to account for CP-AMPAR accumulation. However, we showed that an AMPAR potentiator (ampakine CX929) increased BDNF protein in the NAc, supporting the alternative hypothesis that enhanced NAc AMPAR transmission during incubation led to the increase in BDNF. The time course of both effects supports this hypothesis (Grimm et al., 2003; Wolf and Tseng, 2012; present results). Therefore, future studies should explore the possibility that CP-AMPAR accumulation plays a causal role in elevation of BDNF levels in the NAc during incubation, although other possibilities mentioned above (e.g., anterograde transport of BDNF to the NAc) should also be investigated.

In conclusion, BDNF levels increase in both the NAc core and shell during withdrawal from extended access cocaine self-administration, but this occurs with different time courses and has different functional consequences in the two subregions. These findings help to reconcile seemingly contradictory reports about BDNF's role in cocaine seeking. In addition, our results support the novel hypothesis that the gradual increase in BDNF levels in the NAc during incubation occurs as a result of increased AMPAR transmission, providing a new direction for future studies. The clinical implication of our results is that reducing BDNF signaling might decrease cue-induced cocaine craving at long withdrawal times and thereby help to maintain abstinence.

\section{References}

Altar CA, DiStefano PS (1998) Neurotrophin trafficking by anterograde transport. Trends Neurosci 21:433-437. CrossRef Medline

Altar CA, Cai N, Bliven T, Juhasz M, Conner JM, Acheson AL, Lindsay RM, Wiegand SJ (1997) Anterograde transport of brain-derived neurotrophic factor and its role in the brain. Nature 389:856-860. CrossRef Medline

Bahi A, Boyer F, Chandrasekar V, Dreyer JL (2008) Role of accumbens BDNF and TrkB in cocaine-induced psychomotor sensitization, conditioned place preference and reinstatement in rats. Psychopharmacology 199:169-182. CrossRef Medline

Berglind WJ, See RE, Fuchs RA, Ghee SM, Whitfield TW Jr, Miller SW, McGinty JF (2007) A BDNF infusion into the medial prefrontal cortex suppresses cocaine seeking in rats. Eur J Neurosci 26:757-766. CrossRef Medline

Berglind WJ, Whitfield TW Jr, LaLumiere RT, Kalivas PW, McGinty JF (2009) A single intra-PFC infusion of BDNF prevents cocaine-induced alterations in extracellular glutamate within the nucleus accumbens. J Neurosci 29:3715-3719. CrossRef Medline

Boudreau AC, Wolf ME (2005) Behavioral sensitization to cocaine is associated with increased AMPA receptor surface expression in the nucleus accumbens. J Neurosci 25:9144-9151. CrossRef Medline

Boudreau AC, Milovanovic M, Conrad KL, Nelson C, Ferrario CR, Wolf ME (2012) A protein crosslinking assay for measuring cell surface expression of glutamate receptors subunits in the rodent brain after in vivo treatments. Curr Protocols Neurosci 5.30.1-5.30.19.

Caldeira MV, Melo CV, Pereira DB, Carvalho R, Correia SS, Backos DS, Carvalho AL, Esteban JA, Duarte CB (2007) Brain-derived neurotrophic factor regulates the expression and synaptic delivery of $\alpha$-amino-3-hydroxy-5-methyl-4-isoxazole propionic acid receptor subunits in hippocampal neurons. J Biol Chem 282:12619-12628. CrossRef Medline

Chen WG, Chang Q, Lin Y, Meissner A, West AE, Griffith EC, Jaenisch R, Greenberg ME (2003) Depression of BDNF transcription involves calcium-dependent phosphorylation of MeCP2. Science 302:885-889. CrossRef Medline

Coggeshall RE (1992) A consideration of neural counting methods. Trends Neurosci 15:9-13. CrossRef Medline

Conner JM, Lauterborn JC, Yan Q, Gall CM, Varon S (1997) Distribution of brain-derived neurotrophic factor (BDNF) protein and mRNA in the normal adult rat CNS: evidence for anterograde axonal transport. J Neurosci 17:2295-2313. Medline

Conrad KL, Tseng KY, Uejima JL, Reimers JM, Heng LJ, Shaham Y, Marinelli M, Wolf ME (2008) Formation of accumbens GluR2lacking AMPA receptors mediates incubation of cocaine raving. Nature 454:118-121. CrossRef Medline

Cunningham ME, Stephens RM, Kaplan DR, Greene LA (1997) Autophosphorylation of activation loop tyrosines regulates signaling by the TRK nerve growth factor receptor. J Biol Chem 272:10957-10967. CrossRef Medline

Eisch AJ, Bolaños CA, de Wit J, Simonak RD, Pudiak CM, Barrot M, Verhaagen J, Nestler EJ (2003) Brain-derived neurotrophic factor in the ventral midbrain-nucleus accumbens pathway: a role in depression. Biol Psychiatry 54:994-1005. CrossRef Medline

Ferrario CR, Li X, Wang X, Reimers JM, Uejima JL, Wolf ME (2010) The role of glutamate receptor redistribution in locomotor sensitization to cocaine. Neuropsychopharmacology 35:818-833. CrossRef Medline

Ferrario CR, Loweth JA, Milowanovic M, Ford KA, Galiñanes GL, Heng LJ, Tseng KY, Wolf ME (2011) Alteration in AMPA receptor subunits and TARPs in the rat nucleus accumbens related to the formation of $\mathrm{Ca}^{2+}$ permeable AMPA receptors during the incubation of cocaine craving. Neuropharmacology 61:1141-1151. CrossRef Medline

Filip M, Faron-Górecka A, Kuśmider M, Golda A, Frankowska M, Dziedzicka-Wasylewska M (2006) Alterations in BDNF and trkB mRNAs following acute or sensitizing cocaine treatments and withdrawal. Brain Res 1071:218-225. CrossRef Medline

Fortin DA, Srivastava T, Dwarakanath D, Pierre P, Nygaard S, Derkach VA, Soderling TR (2012) Brain-derived neurotrophic factor activation of CaM-kinase kinase via transient receptor potential canonical channels induces the translation and synaptic incorporation of GluA1-containing calcium-permeable AMPA receptors. J Neurosci 32:8127-8237. CrossRef Medline 
Fukuchi M, Tabuchi A, Tsuda M (2005) Transcriptional regulation of neuronal genes and its effect on neural functions: cumulative mRNA expression of PACAP and BDNF genes controlled by calcium and cAMP signals in neurons. J Pharmacol Sci 98:212-218. CrossRef Medline

Fumagalli F, Di Pasquale L, Caffino L, Racagni G, Riva MA (2007) Repeated exposure to cocaine differently modulates BDNF mRNA and protein levels in rat striatum and prefrontal cortex. Eur J Neurosci 26:2756-2763. CrossRef Medline

Gawin FH, Kleber HD (1986) Abstinence symptomatology and psychiatric diagnosis in cocaine abusers. Arch Gen Psychiatry 43:107-113. CrossRef Medline

Graham DL, Edwards S, Bachtell RK, DiLeone RJ, Rios M, Self DW (2007) Dynamic BDNF activity in nucleus accumbens with cocaine use increases self-administration and relapse. Nat Neurosci 10:1029-1037. CrossRef Medline

Graham DL, Krishnan V, Larson EB, Graham A, Edwards S, Bachtell RK, Simmons D, Gent LM, Berton O, Bolanos CA, DiLeone RJ, Parada LF, Nestler EJ, Self DW (2009) Tropomyosin-related kinase B in the mesolimbic dopamine system: region-specific effects on cocaine reward. Biol Psychiatry 65:696-701. CrossRef Medline

Grimm JW, Hope BT, Wise RA, Shaham Y (2001) Neuroadaptation: incubation of cocaine craving after withdrawal. Nature 412:141-142. CrossRef Medline

Grimm JW, Lu L, Hayashi T, Hope BT, Su TP, Shaham Y (2003) Timedependent increases in brain-derived neurotrophic factor protein levels within the mesolimbic dopamine system after withdrawal from cocaine: implications for incubation of cocaine craving. J Neurosci 23:742-747. Medline

Gualandris A, Jones TE, Strickland S, Tsirka SE (1996) Membrane depolarization induces calcium-dependent secretion of tissue plasminogen activation. J Neurosci 16:2220-2225. Medline

Huang CC, Yeh CM, Wu MY, Chang AY, Chan JY, Chan SH, Hsu KS (2011) Cocaine withdrawal impairs metabotropic glutamate receptordependent long-term depression in the nucleus accumbens. J Neurosci 31:4191-4203. Medline

Huang EJ, Reichardt LF (2003) Trk receptors: roles in neuronal signal transduction. Annu Rev Biochem 72:609-642. CrossRef Medline

Im HI, Hollander JA, Bali P, Kenny PJ (2010) MeCP2 controls BDNF expression and cocaine intake through homeostatic interactions with microRNA-212. Nat Neurosci 13:1120-1127. CrossRef Medline

Isaac JT, Ashby MC, McBain CJ (2007) The role of the GluR2 subunit in AMPA receptor function and synaptic plasticity. Neuron 54:859-871. CrossRef Medline

Ji Y, Lu Y, Yang F, Shen W, Tang TT, Feng L, Duan S, Lu B (2010) Acute and gradual increases in BDNF concentration elicit distinct signaling and functions in neurons. Nat Neurosci 13:302-309. CrossRef Medline

Keifer J, Zheng Z (2010) AMPA receptor trafficking and learning. Eur J Neurosci 32:269-277. CrossRef Medline

Lau AG, Irier HA, Gu J, Tian D, Ku L, Liu G, Xia M, Fritsch B, Zheng JQ, Dingledine R, Xu B, Feng Y (2010) Distinct 3'UTRs differentially regulate activity-dependent translation of brain-derived neurotrophic factor (BDNF). Proc Natl Acad Sci U S A 107:15845-15950. CrossRef Medline

Lauterborn JC, Lynch G, Vanderklish P, Arai A, Gall CM (2000) Positive modulation of AMPA receptors increases neurotrophic expression by hippocampal and cortical neurons. J Neurosci 20:8-21. Medline

Lauterborn JC, Truong GS, Baudry M, Bi X, Lynch G, Gall CM (2003) Chronic elevation of brain-derived neurotrophic factor by ampakines. J Phamacol Exp Ther 307:297-305. CrossRef Medline

Lauterborn JC, Pineda E, Chen LY, Ramirez EA, Lynch G, Gall CM (2009) Ampakines cause sustained increases in brain-derived neurotrophic factor signaling at excitatory synapses without changes in AMPA receptor subunit expression. Neuroscience 159:283-295. CrossRef Medline

Le Foll B, Diaz J, Sokoloff P (2005) A single cocaine exposure increases BDNF and D3 receptor expression: implications for drug-conditioning. Neuroreport 16:175-178. CrossRef Medline

Lessmann V, Gottmann K, Malcangio M (2003) Neurotrophin secretion: current facts and future prospects. Prog Neurobiol 69:341-374. CrossRef Medline

Li W, Keifer J (2008) Coordinate action of pre and postsynaptic brainderived neurotrophic factor is required for AMPAR trafficking and acquisition in vitro classical conditioning. Neuroscience 155:686-697. CrossRef Medline
Li W, Keifer J (2009) BDNF-induced synaptic delivery of AMPAR subunits is differentially dependent on NMDA receptors and requires ERK. Neurobiol Learn Mem 91:243-249. CrossRef Medline

Li X, Wolf ME (2011a) Brain-derived neurotrophic factor rapidly increases AMPA receptor surface expression in rat nucleus accumbens. Eur J Neurosci 34:190-198. CrossRef Medline

Li X, Wolf ME (2011b) Visualization of virus-infected brain-regions using a GFP-illuminating flashlight enables accurate and rapid dissection for biochemical analysis. J Neurosci Methods 201:177-179. CrossRef Medline

Li X, Bahi A, DeJoseph MR, Urban JH, Dreyer JL, Wolf ME (2009) Brainderived neurotrophic factor (BDNF) and AMPA receptor trafficking in the nucleus accumbens core. Soc Neurosci Abstr 35:550.12.

Li X, DeJoseph MR, Bahi A, Dreyer JL, Urban JH, Wolf ME (2010) Brainderived neurotrophic factor (BDNF) and cocaine-induced AMPA receptor plasticity in the rat nucleus accumbens. Soc Neurosci Abstr 36:366.16.

Li X, DeJoseph MR, Bahi A, Dreyer JL, Urban JH, Loweth JA, Wolf ME (2011) The role of BDNF-TrkB signaling during the incubation of cueinduced cocaine craving and its long-term maintenance. Soc Neurosci Abstr 37:67.10

Li YQ, Li FQ, Wang XY, Wu P, Zhao M, Xu CM, Shaham Y, Lu L (2008) Central amygdala extracellular signal-regulated kinase signaling pathway is critical to incubation of opiate craving. J Neurosci 28:13248-13257. CrossRef Medline

Liu QR, Lu L, Zhu XG, Gong JP, Shaham Y, Uhl GR (2006) Rodent BDNF genes, novel promoters, novel splice variants, and regulation by cocaine. Brain Res 1067:1-12. CrossRef Medline

Liu SJ, Zukin RS (2007) $\mathrm{Ca}^{2+}$-permeable AMPA receptors in synaptic plasticity and neuronal death. Trends Neurosci 30:126-134. CrossRef Medline

Lobbestael E, Reumers V, Ibrahimi A, Paesen K, Thiry I, Gijsbers R, Van den Haute C, Debyser Z, Baekelandt V, Taymans JM (2010) Immunohistochemical detection of transgene expression in the brain using small epitope tags. BMC Biotechnol 10:16. CrossRef Medline

Lu L, Dempsey J, Liu SY, Bossert JM, Shaham Y (2004a) A single infusion of brain-derived neurotrophic factor into the ventral tegmental area induces long-lasting potentiation of cocaine seeking after withdrawal. J Neurosci 24:1604-1611. CrossRef Medline

Lu L, Grimm JW, Dempsey J, Shaham Y (2004b) Cocaine seeking over extended withdrawal periods in rats: different time courses of responding induced by cocaine cues versus cocaine priming over the first 6 months. Psychopharmacology 176:101-108. CrossRef Medline

Lu L, Grimm JW, Hope BT, Shaham Y (2004c) Incubation of cocaine craving after withdrawal: a review of preclinical data. Neuropharmacology 47:214-226. CrossRef Medline

Lu L, Wang X, Wu P, Xu C, Zhao M, Morales M, Harvey BK, Hoffer BJ, Shaham Y (2009) Role of ventral tegmental area glial cell line-derived neurotrophic factor in incubation of cocaine craving. Biol Psychiatry 66: 137-145. CrossRef Medline

Lynch G, Gall CM (2006) Ampakines and the threefold path to cognitive enhancement. Trends Neurosci 29:554-562. CrossRef Medline

Mameli M, Halbout B, Creton C, Engblom D, Parkitna JR, Spanagel R, Lüscher C (2009) Cocaine-evoked synaptic plasticity: persistence in the VTA triggers adaptations in the NAc. Nat Neurosci 12:1036-1041. CrossRef Medline

Martinowich K, Hattori D, Wu H, Fouse S, He F, Hu Y, Fan G, Sun YE (2003) DNA methylation-related chromatin remodeling in activity-dependent BDNF gene regulation. Science 302:890-893. CrossRef Medline

McCutcheon JE, Wang X, Tseng KY, Wolf ME, Marinelli M (2011) Calcium-permeable AMPA receptors are present in nucleus accumbens synapses after prolonged withdrawal from cocaine self-administration but not experimenter-administered cocaine. J Neurosci 31:5737-5743. CrossRef Medline

Neisewander JL, Baker DA, Fuchs RA, Tran-Nguyen LT, Palmer A, Marshall JF (2000) Fos protein expression and cocaine-seeking behavior in rats after exposure to a cocaine self-administration environment. J Neurosci 20:798-805. Medline

Paxinos G, Watson C (1998) The rat brain in stereotaxic coordinates. San Diego: Academic.

Pickens CL, Airavaara M, Theberge F, Fanous S, Hope BT, Shaham Y (2011) Neurobiology of the incubation of drug craving. Trends Neurosci 34:411420. CrossRef Medline

Pierce RC, Reeder DC, Hicks J, Morgan ZR, Kalivas PW (1998) Ibotenic 
acid lesions of the dorsal prefrontal cortex disrupt the expression of behavioral sensitization to cocaine. Neuroscience 82:1103-1114. CrossRef Medline

Prakash A, Zhang H, Pandey SC (2008) Innate differences in the expression of brain-derived neurotrophic factor in the regions within the extended amygdala between alcohol preferring and nonpreferring rats. Alchohol Clin Exp Res 32:909-920. CrossRef Medline

Reimers JM, Milovanovic M, Wolf ME (2011) Quantitative analysis of AMPA receptor subunit composition in addiction-related brain regions. Brain Res 1367:223-233. CrossRef Medline

Rex CS, Lauterborn JC, Lin CY, Kramár EA, Rogers GA, Gall CM, Lynch G (2006) Restoration of long-term potentiation in middle-aged hippocampus after induction of brain-derived neurotrophic factor. J Neurophysiol 96:677-685. CrossRef Medline

Robison AJ, Nestler EJ (2011) Transcriptional and epigenetic mechanisms of addiction. Nat Rev Neurosci 12:623-637. CrossRef Medline

Sadri-Vakili G, Kumaresan V, Schmidt HD, Famous KR, Chawla P, Vassoler FM, Overland RP, Xia E, Bass CE, Terwilliger EF, Pierce RC, Cha JH (2010) Cocaine-induced chromatin remodeling increases brainderived neurotrophic factor transcription in the rat medial prefrontal cortex, which alters the reinforcing efficacy of cocaine. J Neurosci 30:11735-11744. CrossRef Medline

Segal RA, Bhattacharyya A, Rua LA, Alberta JA, Stephens RM, Kaplan DR,
Stiles CD (1996) Differential utilization of Trk autophosphorylation sites. J Biol Chem 271:20175-20181. CrossRef Medline

Sommerfeld MT, Schweigreiter R, Barde YA, Hoppe E (2000) Downregulation of the neurotrophin receptor TrkB following ligand binding. J Biol Chem 275:8982-8990. CrossRef Medline

Sorge RE, Stewart J (2005) The contribution of drug history and time since termination of drug taking to footshock stress-induced cocaine seeking in rats. Psychopharmacology 183:210-217. CrossRef Medline

Toda S, McGinty JF, Kalivas PW (2002) Repeated cocaine administration alters the expression of genes in corticolimbic circuitry after a 3-week withdrawal: a DNA macroarray study. J Neurochem 82:1290-1299. CrossRef Medline

Whitfield TW Jr, Shi X, Sun WL, McGinty JF (2011) The suppressive effect of an intra-prefrontal cortical infusion of BDNF on cocaine-seeking is Trk receptor and extracellular signal-regulated protein kinase mitogenactivated protein kinase dependent. J Neurosci 31:834-842. CrossRef Medline

De Wit J, Eggers R, Evers R, Castrén E, Verhaagen J (2006) Long-term adenoassociated viral vector-mediated expression of truncated $\operatorname{TrkB}$ in the adult rat facial nucleus results in motor neuron degeneration. J Neurosci 26:1516-1530. CrossRef Medline

Wolf ME, Tseng KY (2012) Calcium-permeable AMPA receptors in the VTA and nucleus accumbens after cocaine exposure: when, how and why? Front Mol Neurosci 5:72. CrossRef Medline 